Prepared in cooperation with the Great Lakes Restoration Initiative

\title{
Occurrence and Distribution of Fecal Indicator Bacteria and Gene Markers of Pathogenic Bacteria in Great Lakes Tributaries, March-October 2011
}

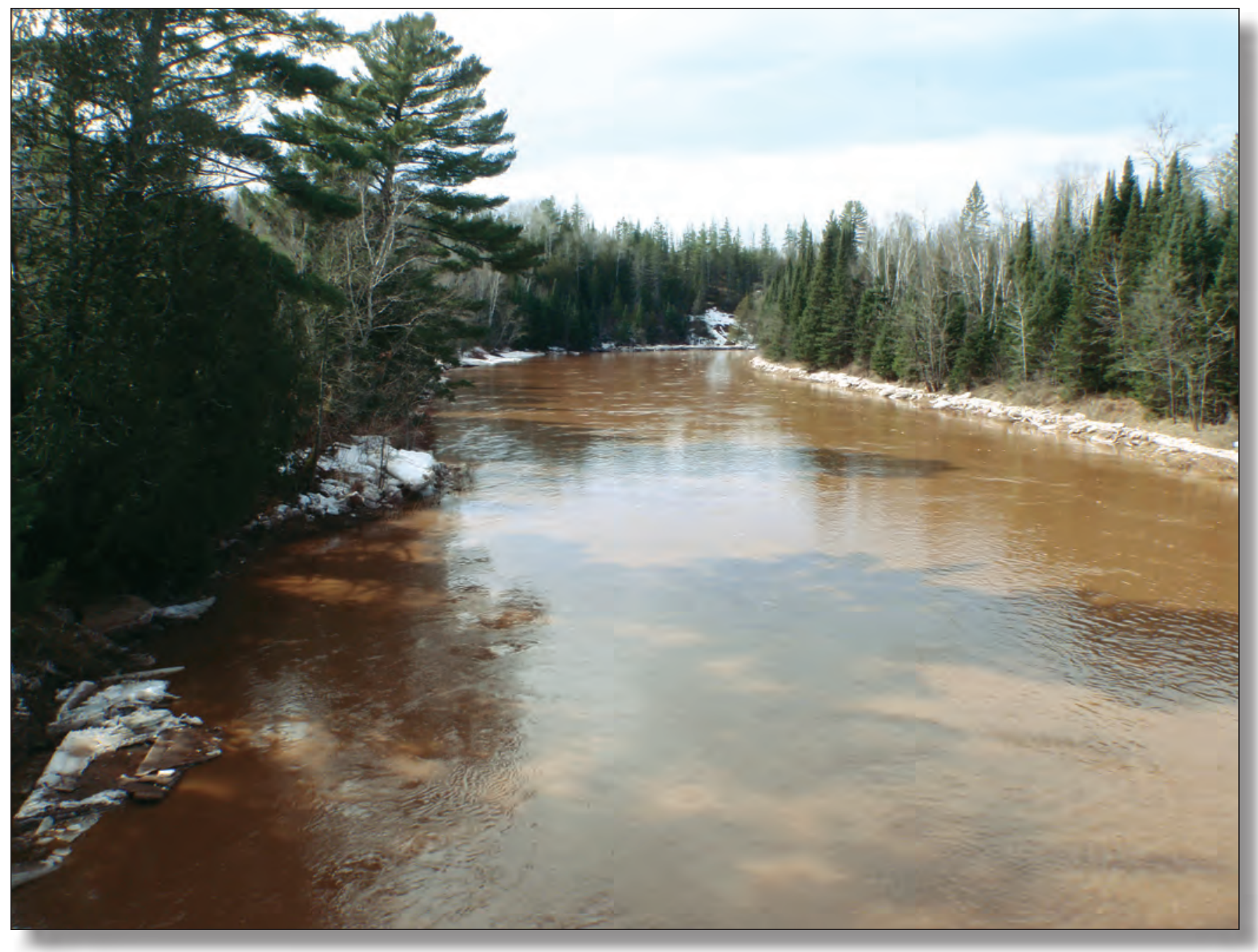

Open-File Report 2015-1013 
Cover: Bad River, Wisconsin (photo by Eric Dantoin, U.S. Geological Survey). 


\section{Occurrence and Distribution of Fecal Indicator Bacteria and Gene Markers of Pathogenic Bacteria in Great Lakes Tributaries, March-October 2011}

By Angela K. Brennan, Heather E. Johnson, Alex R. Totten, and Joseph W. Duris

Prepared in cooperation with the Great Lakes Restoration Initiative

Open-File Report 2015-1013 


\title{
U.S. Department of the Interior SALLY JEWELL, Secretary
}

\section{U.S. Geological Survey Suzette M. Kimball, Acting Director}

\author{
U.S. Geological Survey, Reston, Virginia: 2015
}

For more information on the USGS - the Federal source for science about the Earth, its natural and living resources, natural hazards, and the environment-visit http://www.usgs.gov or call 1-888-ASK-USGS.

For an overview of USGS information products, including maps, imagery, and publications, visit http://www.usgs.gov/pubprod/.

To order this and other USGS information products, visit http://store.usgs.gov/.

Any use of trade, firm, or product names is for descriptive purposes only and does not imply endorsement by the U.S. Government.

Although this information product, for the most part, is in the public domain, it also may contain copyrighted materials as noted in the text. Permission to reproduce copyrighted items must be secured from the copyright owner.

Suggested citation:

Brennan, A.K., Johnson, H.E., Totten, A.R., and Duris, J.W., 2015, Occurrence and distribution of fecal indicator bacteria and gene markers of pathogenic bacteria in Great Lakes tributaries, March-October 2011: U.S. Geological Survey Open-File Report 2015-1013, 29 p., http://dx.doi.org/10.3133/ofr20151013.

ISSN 2331-1258 (online) 


\section{Contents}

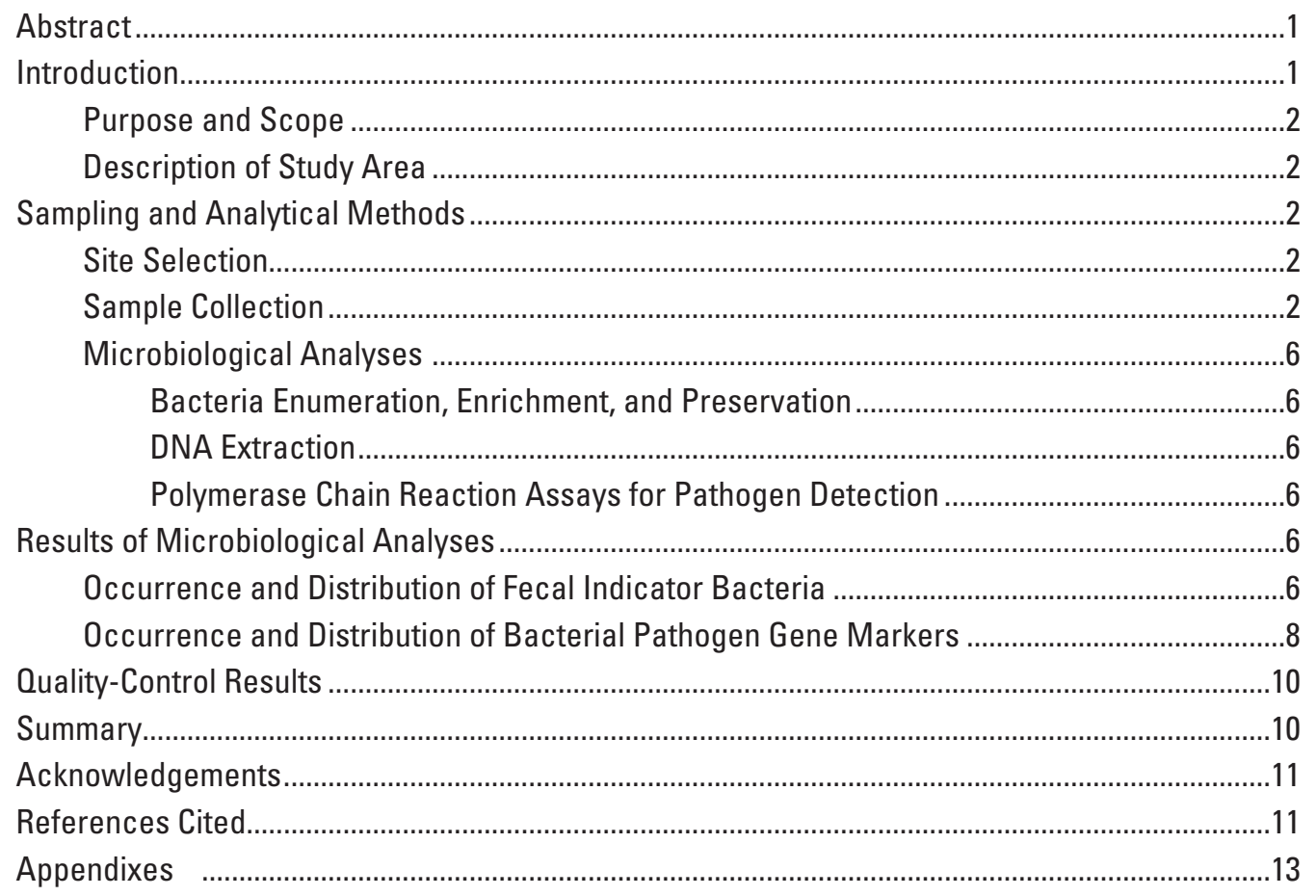

\section{Figures}

1. Graph showing land cover surrounding tributary sites sampled as part of the Great Lakes Restoration Initiative (GLRI) pathogens study ...............................................3

2. Map showing Great Lakes Restoration Initiative (GLRI) USGS tributary sampling locations and number of samples collected for pathogens study, 2011 .........................

3. Graph showing frequency of samples testing positive for pathogen gene markers ........8

4. Graph showing percentage of pathogen gene markers in relation to water quality criteria.

\section{Tables}

1. Great Lakes Restoration Initiative (GLRI) pathogens study sampling locations, $2011 \ldots . .5$

2. Growth media, target organisms, and incubation temperature requirements for the Great Lakes Restoration Initiative (GLRI) pathogens study............................................

3. Selected pathogen gene targets and virulence traits of the organism............................7

4. Summary of the frequency of pathogen gene detections in a single sample....................8

5. Percentage of samples that tested positive for pathogenic gene markers during high-flow and normal-flow conditions .........................................................................

6. Relative standard deviation of field replicates for quantitative microbial methods in the Great Lakes Restoration Initiative (GLRI) pathogens study..................................10

7. Frequency of agreement between field replicates for qualitative microbial methods in the Great Lakes Restoration Initiative (GLRI) pathogens study 


\section{Conversion Factors}

\begin{tabular}{|c|c|c|}
\hline Multiply & By & To obtain \\
\hline \multicolumn{3}{|c|}{ Length } \\
\hline mile (mi) & 1.609 & kilometer $(\mathrm{km})$ \\
\hline \multicolumn{3}{|c|}{ Area } \\
\hline square mile $\left(\mathrm{mi}^{2}\right)$ & 2.590 & square kilometer $\left(\mathrm{km}^{2}\right)$ \\
\hline \multicolumn{3}{|c|}{ Volume } \\
\hline milliliter $(\mathrm{mL})$ & 1,000 & microliter $(\mu \mathrm{L})$ \\
\hline \multicolumn{3}{|c|}{$\begin{array}{l}\text { Temperature in degrees Celsius }\left({ }^{\circ} \mathrm{C}\right) \text { may be converted to degrees } \\
\text { Fahrenheit }\left({ }^{\circ} \mathrm{F}\right) \text { as follows: }{ }^{\circ} \mathrm{F}=\left(1.8 \times^{\circ} \mathrm{C}\right)+32\end{array}$} \\
\hline \multicolumn{3}{|c|}{$\begin{array}{l}\text { Horizontal coordinate information is referenced to North American } \\
\text { Datum of } 1983 \text { (NAD 83). }\end{array}$} \\
\hline \multicolumn{3}{|c|}{$\begin{array}{l}\text { Concentrations of fecal indicator bacteria are given in colony- } \\
\text { forming units per } 100 \text { milliliters (CFU/100 mL). }\end{array}$} \\
\hline
\end{tabular}




\title{
Abbreviations used in report
}

\author{
CDC Centers for Disease Control and Prevention \\ CFU colony-forming unit \\ DNA Deoxyribonucleic acid \\ E. coli Escherichia coli \\ EWI equal-width-increment \\ FIB Fecal indicator bacteria \\ GLRI Great Lakes Restoration Initiative \\ MI-BaRL USGS Michigan Bacteriological Research Laboratory \\ MI-WSC USGS Michigan Water Science Center \\ PBS phosphate buffered saline \\ PCR polymerase chain reaction \\ OC quality control \\ RSD relative standard deviation \\ STEC Shiga-toxin producing Escherichia coli \\ EPA U.S. Environmental Protection Agency \\ USGS U.S. Geological Survey \\ WOC water quality criteria
}





\title{
Occurrence and Distribution of Fecal Indicator Bacteria and Gene Markers of Pathogenic Bacteria in Great Lakes Tributaries, March-October 2011
}

\author{
By Angela K. Brennan, Heather E. Johnson, Alex R. Totten, and Joseph W. Duris
}

\begin{abstract}
From March through October 2011, the U.S. Geological Survey (USGS), conducted a study to determine the frequency of occurrence of pathogen gene markers and densities of fecal indicator bacteria (FIB) in 22 tributaries to the Great Lakes. This project was funded as part of the Great Lakes Restoration Initiative (GLRI) and included sampling at 22 locations throughout 6 states that border the Great Lakes.

A total of 177 environmental samples were collected at USGS streamgaging stations during both normal-flow and high-flow conditions and were analyzed by the Michigan Bacteriological Research Laboratory at the USGS Water Science Center in Lansing, Michigan.

Water samples were analyzed for the presence of FIB concentrations (FIB; fecal coliform bacteria, Escherichia coli [E. coli], and enterococci) by using membrane filtration and serial dilution methods. The resulting enrichments from standard culturing of the samples were then analyzed by using polymerase chain reaction (PCR) to determine the occurrence of pathogen gene markers for Shigella species, Campylobacter jejuni and coli, Salmonella species, and pathogenic E. coli, including Shiga toxin-producing E. coli (STEC).
\end{abstract}

\section{Introduction}

In 2009, the Great Lakes Restoration Initiative (GLRI) was started as an interagency initiative to protect and restore the Great Lakes. This report describes data collected in 2011 as part of the U.S. Geological Survey (USGS) GLRI effort led by the Michigan Water Science Center (MI-WSC), in conjunction with USGS Water Science Centers in Indiana, Minnesota, Ohio, New York, and Wisconsin, and complements the ongoing USGS GLRI Great Lakes Nutrient and Sediment Loadings study (GLRI Loadings study) being conducted at the same sampling locations.
The microbiological monitoring network for this study consisted of 22 sampling locations, representing multiple land-use types, drainage areas, and soil characteristics typical of the Great Lakes region. Samples were collected to better understand the occurrence and distribution of fecal indicator bacteria (FIB) and selected bacterial pathogens that are commonly associated with waterborne illnesses.

Within the broad FIB groups (Escherichia coli [E. coli], fecal coliforms, and enterococci), there are specific strains of bacteria that are pathogenic (infection causing) to humans. The bacterial pathogen gene markers evaluated in this study included genes from the genera Shigella, Campylobacter (jejuni and coli) and Salmonella. In addition, several genes were also evaluated from a class of pathogenic $E$. coli known as Shiga toxin-producing E. coli (STEC), which includes $E$. coli $\mathrm{O} 157: \mathrm{H} 7$.

Fecally derived bacterial pathogens have long been known to be a health threat to humans, and exposure to these pathogens can result in illness and occasionally even death (Centers for Disease Control and Prevention [CDC], 2012b). STEC, including E. coli $\mathrm{O} 157: \mathrm{H} 7$, can cause illness ranging from mild intestinal disease to severe kidney complications and death in animals and humans (CDC, 2012d). Shigella's pathogenicity functions similarly to that of STEC; however, Shigella mainly affects humans. Campylobacter is one of the most common causes of diarrheal illness in the United States, and symptoms include cramping, abdominal pain, and fever (CDC, 2012a). Salmonella infection can cause diarrhea, fever, and abdominal cramps, and severe cases can even lead to death (CDC, 2012c).

Current methods for evaluating recreational and drinking water safety typically rely on the enumeration of FIB (U.S. Environmental Protection Agency [EPA], 2012). FIB are used to indicate the potential for illness associated with fecal contamination (EPA, 2012). Primary contact refers to watercontact activities where immersion and ingestion are likely, such as swimming, water skiing, and diving. Even though most tributaries are not used for "primary contact" recreational 
water activities, many of these major tributaries enter the Great Lakes at or near a beach which is designated as a recreation area. Most tributaries are used for partial, or secondary, contact recreation, indicating water activities where there is the potential of submergence, such as boating and fishing. FIB concentrations and the occurrence of bacterial pathogens associated with these bodies of water are important, not only to partial contact recreational users in rivers but ultimately to primary contact recreational users at Great Lakes beaches. The partial body contact recreation standard (Dufour and Ballantine, 1986) was used for data interpretation for this report because the EPA 2012 guidance does not include a numerical standard for partial body contact in recreational waters.

\section{Purpose and Scope}

This report presents data obtained during a Great Lakeswide study conducted in 2011 by the USGS as part of the GLRI. The purpose of this study was to determine the occurrence and distribution of FIB and pathogenic gene markers within 22 major tributaries to the Great Lakes. Normal-flow and high-flow samples were analyzed for FIB and for pathogens Shigella, Campylobacter (jejuni and coli), Salmonella, and STEC, which included E. coli O157:H7. The relations of FIB concentrations and bacterial pathogen gene occurrence to recreational water quality criteria were also assessed.

\section{Description of Study Area}

Approximately 132,208 miles of tributaries (EPA and USGS, 2012), with a drainage area of almost 295,000 square miles (Great Lakes Information Network, 2013), drain into the Great Lakes from six states (Indiana, Michigan, Minnesota, New York, Ohio, Wisconsin) and Canada. The 22 monitoring locations are grouped on the basis of predominant land cover surrounding the major tributaries in this study (fig. 1) (USGS, 2011) and were distributed geographically throughout the Great Lakes region of the United States (fig. 2).

\section{Sampling and Analytical Methods}

\section{Site Selection}

All sampling locations were at USGS streamgaging stations. Twenty-two sampling locations (fig. 2, table 1) were selected (out of 59 GLRI Loadings study sites) to create a geographically distributed study and to address the variability in land cover throughout the Great Lakes region. Sampling locations, as well as timing of sample collection, were designed to complement the GLRI Loadings study (USGS, 2014). In addition to those sites selected from the GLRI Loadings study, the Paw Paw River at Riverside, MI, was included as a sampling location for this study because the site was routinely visited as part of another USGS MI-WSC project.

\section{Sample Collection}

Hydrologic conditions were determined on the basis of mean daily discharge ${ }^{1}$ at each USGS streamgage on the date of collection, calculated from date of first record to current. Conditions were evaluated such that if daily discharge ${ }^{2}$ was greater than or equal to the 75th percentile, the corresponding sample was considered a high-flow sample; otherwise, the sample was considered a normal-flow sample. Owing to a short period of record, the Grand River at Grand Rapids station was used to estimate hydrologic conditions for the Grand River at Eastmanville station. Water samples were collected during normal-flow conditions from March through October 2011 in an effort to target the recreational water season. Samples were also collected during high-flow conditions (storm events), but sampling frequency varied among sites in response to the frequency of storm events and availability of staff (table 1).

The sampling frequency depended on the sampling schedule of the GLRI Loadings study. Some sites were sampled more often than others, including those sites targeted for analysis of certain chemical constituents (such as wastewater indicator compounds) in addition to FIB and pathogenic gene markers.

Normal-flow and high-flow sampling events typically coincided with GLRI Loadings study sampling. All samples were collected by USGS personnel using either equal-widthincrement (EWI) or multiple vertical sampling techniques designed to account for the variable distribution of constituents across the stream channel and throughout the water column (USGS, 2006). EWI samples were typically collected off bridges by using a crane apparatus with an attached DH-95 depth integrating sampler, or from boats. There were instances when wading measurements were made, but typically only during normal-flow conditions.

For each sample, a 1-liter sterile high density polyethylene (HDPE) sample bottle was filled to the shoulder to allow some head space for sample mixing. Once collected, water samples were placed on ice in a cooler (away from ultraviolet light) and shipped overnight to the MI-BaRL (Michigan Bacteriological Research Laboratory) at the MI-WSC in Lansing, Michigan. Upon receipt of the shipments, sample information and streamflow condition were logged in to the laboratory database system, and samples were placed into the refrigerator at 4-7 degrees Celsius $\left({ }^{\circ} \mathrm{C}\right)$ until processing and analysis (typically the same day).

A total of 177 water samples were collected, including field quality-control (QC) samples. There were 59 normalflow samples and 54 high-flow samples used for data analysis. Quality-control samples included 21 field blank samples, 21 source solution blank samples, and 22 field replicate samples.

\footnotetext{
${ }^{1}$ The arithmetic mean of discharges for all instances of a particular calendar day on record or for a specific set of years.

${ }^{2}$ The arithmetic mean discharge for a single day.
} 


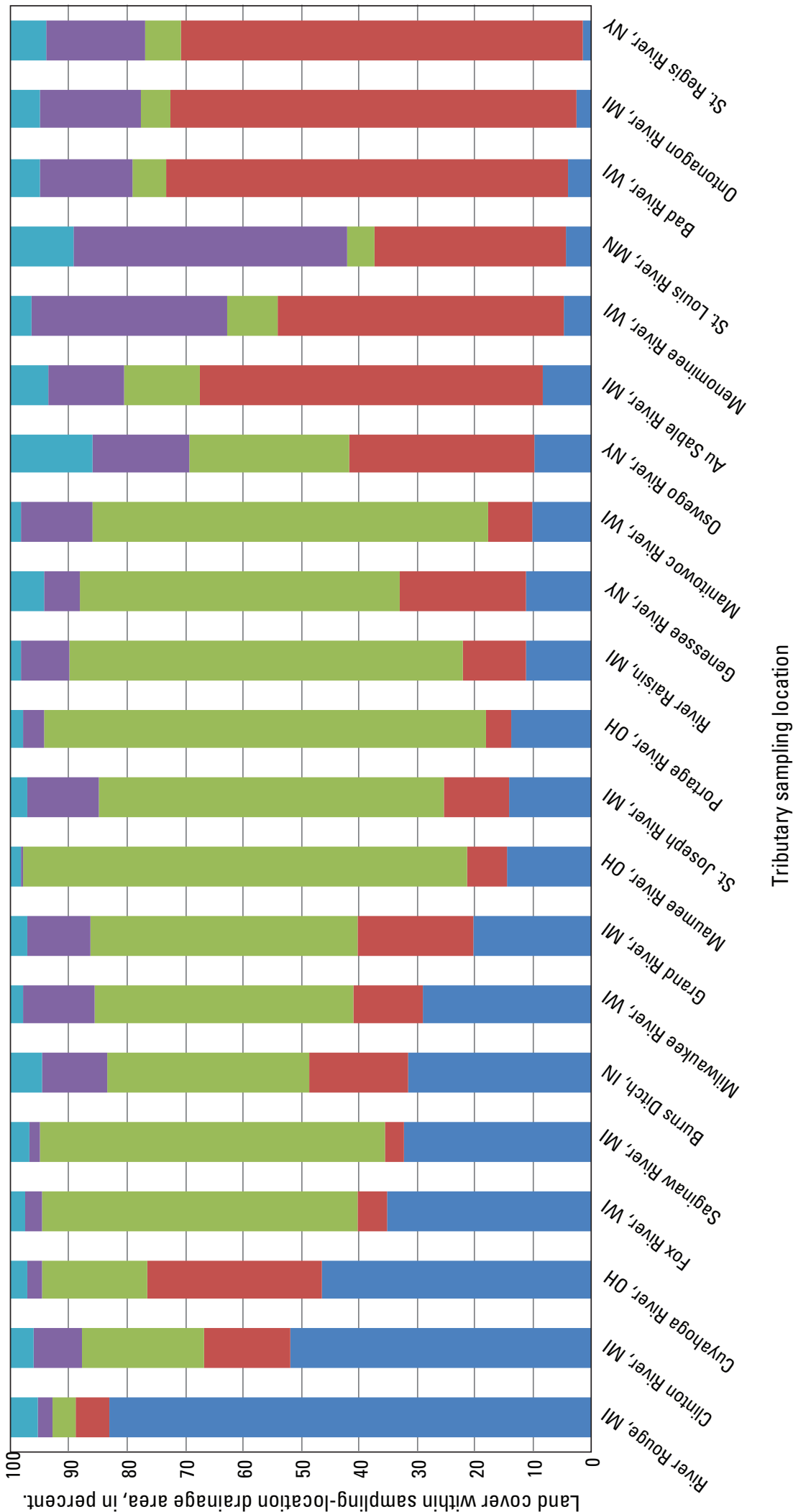




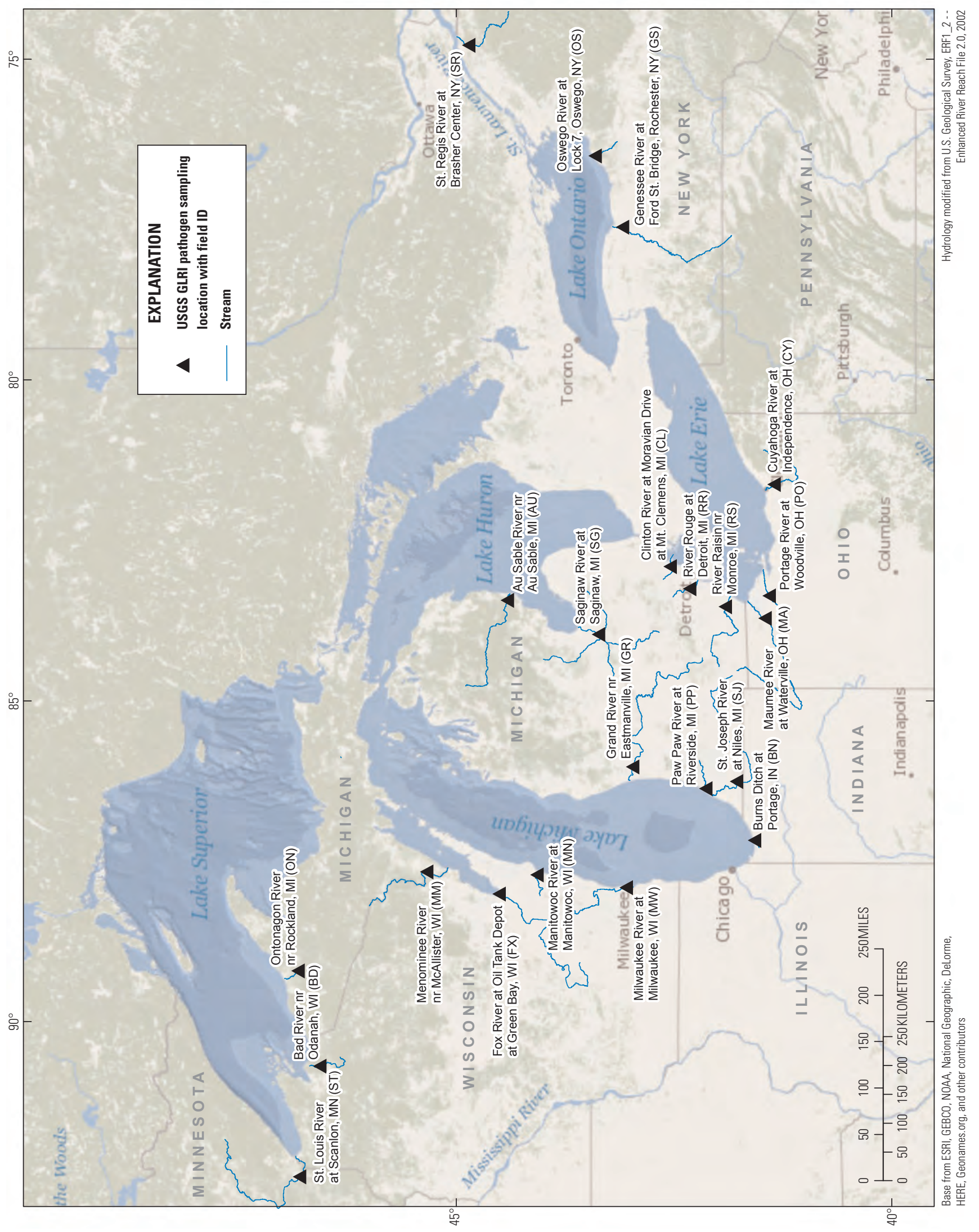

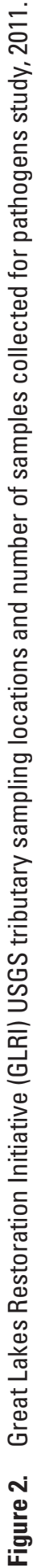


Field blanks, source solution blanks, and field replicate samples were collected according to the methods described in the USGS National Field Manual, with inorganic-grade reagent water being used as the sample medium (USGS, 2006).

Twelve samples were excluded from the data analysis because the samples exceeded the holding time (48 hours) established by the MI-BaRL for FIB culturing for nonregulatory purposes. There were also three instances where the bacteria plates were uncountable (coded as "unc"), owing to smearing or a heavy amount of particulates on the filter. A total of 165 water samples were included in the final analysis.

Table 1. Great Lakes Restoration Initiative (GLRI) pathogens study sampling locations, 2011.

$[\mathrm{nr}$, near]

\begin{tabular}{|c|c|c|c|c|}
\hline USGS site name & $\begin{array}{c}\text { USGS site } \\
\text { identification } \\
\text { number }\end{array}$ & $\begin{array}{c}\text { Field } \\
\text { ID }\end{array}$ & $\begin{array}{c}\text { Number of samples } \\
\text { collected during } \\
\text { normal flow }\end{array}$ & $\begin{array}{c}\text { Number of samples } \\
\text { collected during } \\
\text { high flow }\end{array}$ \\
\hline \multicolumn{5}{|c|}{ Indiana } \\
\hline Burns Ditch at Portage & 04095090 & $\mathrm{BN}$ & 3 & 4 \\
\hline \multicolumn{5}{|l|}{ Michigan } \\
\hline Au Sable River nr Au Sable & 04137500 & $\mathrm{AU}$ & 5 & 1 \\
\hline Clinton River at Moravian Drive at Mt. Clemens & 04165500 & $\mathrm{CL}$ & 0 & 2 \\
\hline Grand River nr Eastmanville & 04119400 & GR & 0 & 5 \\
\hline Ontonagon River nr Rockland & 04040000 & $\mathrm{ON}$ & 8 & 1 \\
\hline Paw Paw River at Riverside & 04102500 & PP & 2 & 5 \\
\hline River Rouge at Detroit & 04166500 & $\mathrm{RR}$ & 1 & 2 \\
\hline River Raisin nr Monroe & 04176500 & RS & 2 & 0 \\
\hline Saginaw River at Saginaw & 04157000 & SG & 5 & 3 \\
\hline St. Joseph River at Niles & 04101500 & SJ & 3 & 4 \\
\hline \multicolumn{5}{|c|}{ Minnesota } \\
\hline St. Louis River at Scanlon & 04024000 & $\mathrm{ST}$ & 7 & 2 \\
\hline \multicolumn{5}{|c|}{ New York } \\
\hline Genessee River at Ford St. Bridge at Rochester & 04231600 & GS & 3 & 3 \\
\hline Oswego River at Lock 7 at Oswego & 04249000 & OS & 4 & 4 \\
\hline St. Regis River at Brasher Center & 04269000 & SR & 5 & 5 \\
\hline \multicolumn{5}{|c|}{ Ohio } \\
\hline Cuyahoga River at Independence & 04208000 & $\mathrm{CY}$ & 1 & 4 \\
\hline Maumee River at Waterville & 04193500 & MA & 2 & 1 \\
\hline Portage River at Woodville & 04195500 & $\mathrm{PO}$ & 0 & 3 \\
\hline \multicolumn{5}{|c|}{ Wisconsin } \\
\hline Bad River nr Odanah & 04027000 & $\mathrm{BD}$ & 3 & 1 \\
\hline Fox River at Oil Tank Depot at Green Bay & 040851385 & FX & 1 & 1 \\
\hline Menominee River nr McAllister & 04067500 & $\mathrm{MM}$ & 2 & 0 \\
\hline Manitowoc River at Manitowoc & 04085427 & $\mathrm{MN}$ & 1 & 1 \\
\hline Milwaukee River at Milwaukee & 04087170 & MW & 1 & 1 \\
\hline
\end{tabular}




\section{Microbiological Analyses}

\section{Bacteria Enumeration, Enrichment, and Preservation}

Water samples were analyzed for the presence of FIB and FIB concentrations by using standard membrane filtration and serial dilution methods (Myers and others, 2014). Fecal coliform bacteria were analyzed according to standard methods of the American Public Health Association and others (1998), E. coli bacteria were analyzed according to EPA method 1603 (EPA, 2009a), and enterococci bacteria were analyzed according to EPA method 1600 (EPA, 2009b). Media were prepared according to manufacturer's instructions.

A volume of 50 milliliters $(\mathrm{mL})$ of sample water was filtered through a 0.45 -micrometer-pore-size nylon-membrane filter (Advantec, USA) by means of aseptic techniques. The enriched filter was then placed on a selective growth medium for enumeration and enrichment of target bacterial pathogen groups and incubated at the optimal temperature (table 2).

The filters with $E$. coli, enterococci, and fecal coliform bacteria growth were transferred to a vial containing $1 \mathrm{~mL}$ of phosphate buffered saline solution (PBS), preserved with 20 percent glycerol, and frozen at $-70{ }^{\circ} \mathrm{C}$ until further analysis; these samples are referred to as "glycerol stocks." The filters with Campylobacter and Salmonella growth were aseptically removed from the Gram Negative and Bolton Broth enrichments, and the remaining culture was centrifuged to form a pellet. The supernatant was decanted, and the pellet was resuspended in $1 \mathrm{~mL}$ of PBS solution and preserved with 20 percent glycerol and frozen at $-70{ }^{\circ} \mathrm{C}$ until deoxyribonucleic acid (DNA) extraction.

\section{DNA Extraction}

Glycerol stocks were thawed at room temperature and DNA was extracted by using the Qiagen QIAamp ${ }^{\circledR}$ DNA Mini Kit (Qiagen, USA), following the manufacturers protocol. DNA concentrations and purity were determined with a NanoDrop spectrophotometer (Thermo Scientific, USA). DNA was then stored at $-20{ }^{\circ} \mathrm{C}$ until needed for Polymerase Chain Reaction (PCR) analysis for the selected gene targets (table 3 ).

\section{Polymerase Chain Reaction Assays for Pathogen Detection}

Samples were analyzed by using PCR to determine the occurrence of pathogen gene markers for Shigella sonnei, Campylobacter jejuni and coli, Salmonella, and STEC. The primer sequences, positive controls, reaction details, and quality-control procedures used for the detection of the pathogens by PCR listed in table 3 were based on previously published studies (Haack and others, 2013).
All PCR assays were performed by using 1 microliter of DNA solution, representing $0.1-85$ nanograms of template DNA, which was isolated from the appropriate growth enrichment. Results from these analyses indicated whether the target genes were present or absent in the sample above the method detection limit; however, PCR does not quantify the genes present. In order for the gene to be detected, the organism had to grow on the appropriate medium, and therefore must have been viable in the sample.

Laboratory filtration blanks were processed daily with every set of samples on all growth media and enrichments to ensure that the laboratory equipment was sterile and that aseptic laboratory techniques were being followed. One set of laboratory replicates was processed weekly on all growth media and enrichments to quantify method variability. If contamination was found in the laboratory blanks, either sample results were discarded or samples were rerun.

Standard quality-assurance and quality-control procedures were followed for all PCR reactions (EPA, 2004). Detection limits for all PCR reactions were determined by using serial dilution of DNA from control organisms. For approximately every 20 samples of any given PCR assay, PCR positive controls (DNA extracted from bacteria known to contain the target gene) and PCR negative controls (no template reactions) were included.

\section{Results of Microbiological Analyses}

Of the 177 water samples collected, 12 samples were omitted from the data analysis because of holding-time violations and 64 of the samples were collected for the analysis of quality control. The 165 samples included in the analyses were assessed for occurrence and distribution of FIB during normal and high flows and for whether the samples exceeded the water quality criteria. These samples were also analyzed for specific pathogen genes by using PCR. Fecal indicator bacteria results are included in the USGS National Water Information System (NWIS) database.

\section{Occurrence and Distribution of Fecal Indicator Bacteria}

Fecal coliform concentrations ranged from $<2$ to 950 colony-forming units per $100 \mathrm{~mL}$ (CFU/100 mL), E. coli concentrations ranged from $<2$ to $26,000 \mathrm{CFU} / 100 \mathrm{~mL}$, and enterococci concentrations ranged from $<2$ to 31,000 CFU/100 mL. Fecal indicator bacteria concentrations for all samples are presented in appendix 1.

The lowest $E$. coli concentrations were recorded at the $\mathrm{Au}$ Sable River near Au Sable, MI (AU) (during high and normal flows), and the St. Joseph River at Niles, MI (during normal flow) (SJ). The highest $E$. coli concentrations were recorded at 
the River Rouge at Detroit, MI (during high flow) (RR). The lowest enterococci concentrations were recorded at the $\mathrm{Au}$ Sable River near Au Sable, MI (AU) (during high and normal flows), and the Oswego River at Lock 7 at Oswego, NY (OS) (during high flow). The highest enterococci concentrations were recorded at the River Rouge at Detroit, MI (RR) (during high flow). The lowest $E$. coli and enterococci concentrations were found at sites dominated by forest and agricultural land cover, whereas the highest $E$. coli and enterococci concentrations were recorded at sites dominated by urban development.

Enterococci and $E$. coli concentrations were evaluated on the basis of whether the data met or exceeded the 1986 EPA criterion for moderate full body contact recreation for freshwater for a single sample (Dufour and Ballantine, 1986). The moderate full body contact recreation criterion was considered most applicable for this study given the type of recreation typically found on rivers; for example, kayaking, canoeing, and fishing. The moderate full body contact criterion for enterococci for a single sample is greater than or equal to $78 \mathrm{CFU} / 100 \mathrm{~mL}$; and for $E$. coli, the recreation criterion is greater than or equal to $298 \mathrm{CFU} / 100 \mathrm{~mL}$ for a single sample. Of 112 samples analyzed for FIB concentrations, 21 percent of samples exceeded the EPA recreation criterion for E. coli, and 40 percent of samples exceeded the criterion for enterococci.

During high-flow events, 43 percent of all samples exceeded the EPA recreation criterion for E. coli, and 61 percent of samples exceeded the criterion for enterococci. During normal-flow conditions, about 2 percent of samples exceeded the criterion for $E$. coli, and about 21 percent of samples exceeded the criterion for enterococci.

Table 2. Growth media, target organisms, and incubation temperature requirements for the Great Lakes Restoration Initiative (GLRI) pathogens study.

[mL, milliliters; ${ }^{\circ} \mathrm{C}$, degrees Celsius; E. coli, Escherichia coli $]$

\begin{tabular}{|c|c|c|c|}
\hline Growth media & Organism or method & $\begin{array}{c}\text { Volume } \\
\text { filtered (mL) }\end{array}$ & $\begin{array}{c}\text { Incubation temperature and time } \\
\text { requirement }\end{array}$ \\
\hline $\mathrm{mFC}$ & $\begin{array}{l}\text { Fecal coliform bacteria } \\
\text { (E. coli, Shigella) }\end{array}$ & 50 & $44.5^{\circ} \mathrm{C} \pm 0.5^{\circ} \mathrm{C}$ for $22-24$ hours \\
\hline Modified mTEC & E. coli & $50,10,1$ & $\begin{array}{l}35-37^{\circ} \mathrm{C} \text { for } 2 \text { hours, then } 44.5^{\circ} \mathrm{C} \\
\quad \pm 0.5^{\circ} \mathrm{C} \text { for } 20-22 \text { hours }\end{array}$ \\
\hline $\mathrm{mEI}$ & Enterococci & $50,10,1$ & $41^{\circ} \mathrm{C} \pm 0.5^{\circ} \mathrm{C}$ for $22-24$ hours \\
\hline $\begin{array}{l}\text { Bolton Broth (BB) with Preston }{ }^{1} \\
\text { supplement }\end{array}$ & Campylobacter & 50 & $\begin{array}{l}37{ }^{\circ} \mathrm{C} \text { for } 4 \text { hours, then } 42^{\circ} \mathrm{C} \\
\text { for } 40-44 \text { hours }\end{array}$ \\
\hline Gram Negative Broth (GN) & Salmonella & 50 & $37^{\circ} \mathrm{C} \pm 1.0^{\circ} \mathrm{C}$ for $22-24$ hours \\
\hline
\end{tabular}

${ }^{1}$ Oxoid, Cambridge, United Kingdom.

Table 3. Selected pathogen gene targets and virulence traits of the organism.

[E. coli, Escherichia coli]

\begin{tabular}{lll}
\hline \multicolumn{1}{c}{ Pathogen } & \multicolumn{1}{c}{ Gene target } & \multicolumn{1}{c}{ Virulence trait } \\
\hline E. coli & $e a e A$ & Attachment \\
E. coli & $s t x 2$ & Severe toxin \\
E. coli & $s t x 1$ & Moderate toxin \\
E. coli & $r f b O 157$ & Common outbreak strain \\
Shigella & $i p a H$ & Invasion \\
Salmonella & $i n v A$ & Invasion \\
Salmonella & $s p v C$ & Multiple virulence traits \\
Campylobacter jejuni and coli & $16 s \mathrm{rDNA}$ (Campy) & Pathogenic species marker \\
\hline
\end{tabular}




\section{Occurrence and Distribution of Bacterial Pathogen Gene Markers}

Data from the E. coli pathogen analysis showed that 68 percent of samples contained the eaeA gene, 20 percent of samples contained the stx 2 gene, 12 percent of samples contained the stx 1 gene, and 11 percent of samples contained the rfbO157 gene (fig. 3). Data from the Shigella analysis showed that 6 percent of samples contained the ipaH gene. Data from the Salmonella analysis showed that 7 percent of samples contained the invA gene and 14 percent of samples contained the $s p v C$ gene. Data from the Campylobacter analysis showed that 9 percent of samples contained the 16 s rDNA gene (fig. 3).
Detections of bacterial pathogen gene markers by site and by sample are listed in appendix 3 .

The frequency of pathogen gene markers detected in each sample is summarized in table 4 . The greatest number of pathogen gene markers detected in any one sample was seven (River Rouge at Detroit, MI, during a May 26, 2011, high-flow event). This same May 26, 2011 sample from the River Rouge also contained the highest $E$. coli and enterococci concentrations of samples collected during this project (E. coli value of 26,000 CFU/100 mL; enterococci value, 31,000 CFU/100 $\mathrm{mL})$.

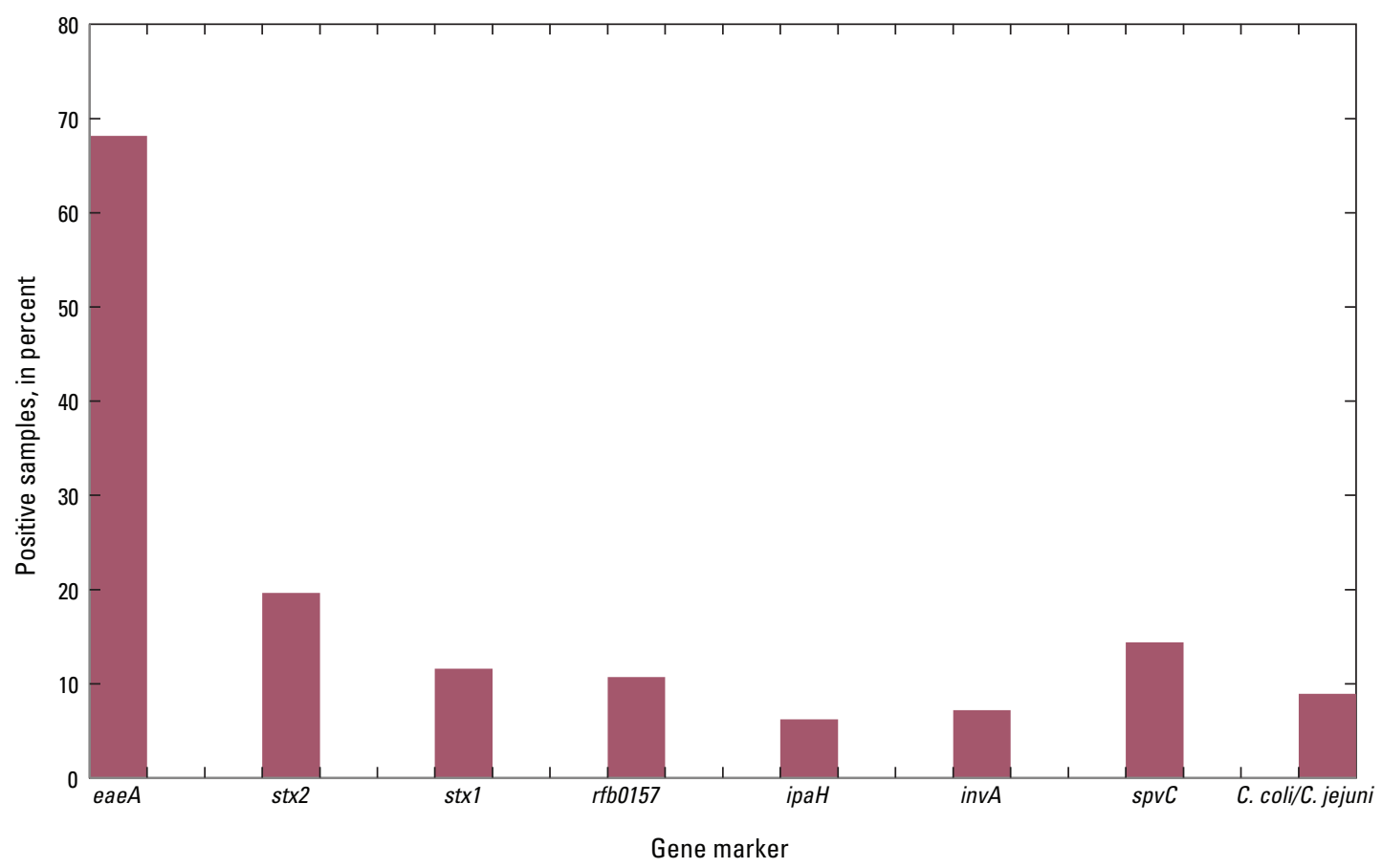

Figure 3. Frequency of samples testing positive for pathogen gene markers (C. coli, Campylobacter coli; $C$. jejuni, Campylobacter jejuni).

Table 4. Summary of the frequency of pathogen gene detections in a single sample.

$[<$, less than $]$

\begin{tabular}{|c|c|c|c|c|c|c|c|c|c|}
\hline \multirow{3}{*}{ Flow conditions } & \multicolumn{9}{|c|}{ Number of bacterial pathogen genes present } \\
\hline & 0 & 1 & 2 & 3 & 4 & 5 & 6 & 7 & 8 \\
\hline & \multicolumn{9}{|c|}{ Percentage of samples in which the indicated number of genes were detected } \\
\hline High flow & 10 & 12 & 13 & 2 & 3.5 & 6 & 0 & 1 & 0 \\
\hline Normal flow & 16 & 25 & 10 & 1 & $<1$ & 0 & 0 & 0 & 0 \\
\hline Total percent detection & 26 & 37 & 23 & 3 & 4 & 6 & 0 & 1 & 0 \\
\hline
\end{tabular}


For those samples in which 3 or more genes were present, 14 of the 16 samples were collected during high-flow conditions.

Pathogen frequency was analyzed in relation to hydrologic condition among all sites, as illustrated in figure 4. Overall, a higher percentage of samples tested positive for pathogens under high-flow conditions than during normal-flow conditions. For Campylobacter, the differences in the percentage of samples that were positive for pathogens between highand normal-flow conditions were less obvious. The invA gene for Salmonella was found only during high flows.
The frequencies of pathogen gene occurrence in samples that met and exceeded the EPA criteria for moderate full body contact recreation for $E$. coli and enterococci were compared for the 22 sites (table 5). Fisher's Exact Test was run to determine if there was a significant difference ( $p$-value less than 0.05 ) between gene detection in samples that met or exceeded the water quality criteria. Overall, there was a greater occurrence of pathogen gene markers in samples that exceeded the moderate full body contact recreation criteria for both $E$. coli and enterococci, the exception being a greater occurrence of the ipaH gene marker for Shigella in samples that met the criterion for E. coli.

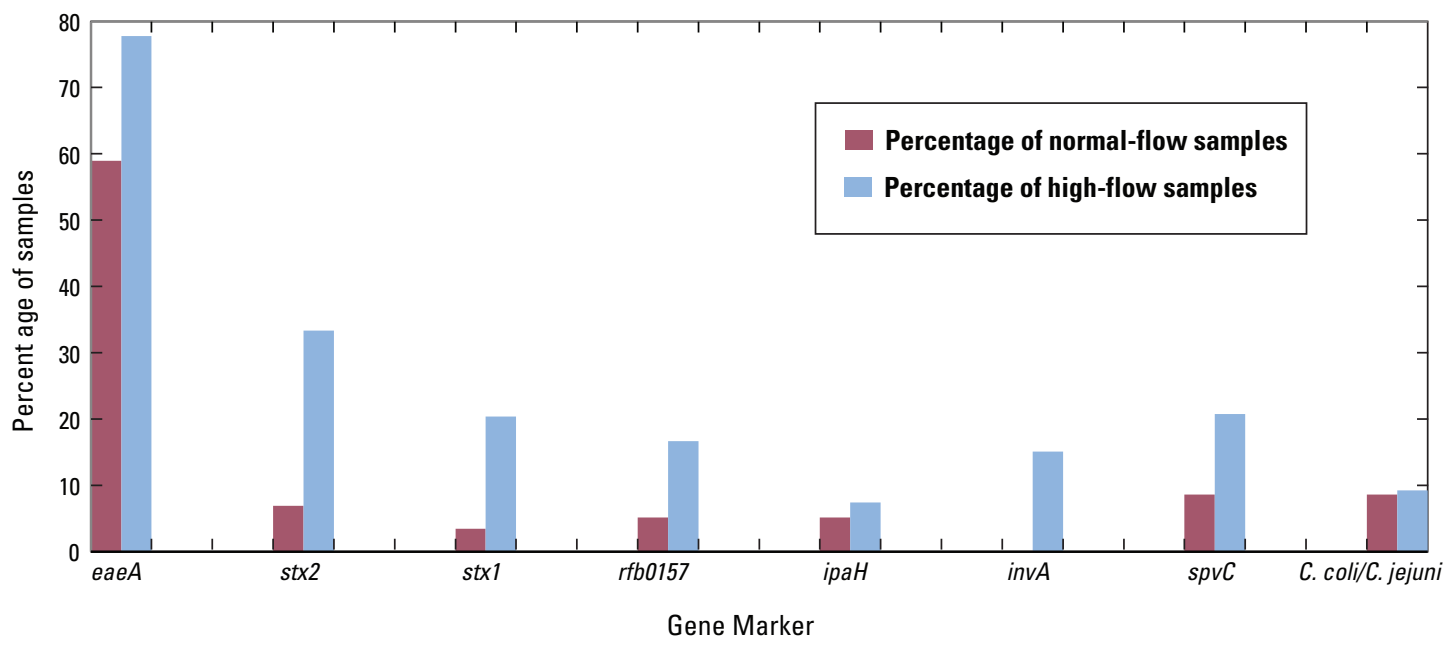

Figure 4. Percentage of pathogen gene markers in relation to water quality criteria (C. coli, Campylobacter coli; C. jejuni, Campylobacter jejuni).

Table 5. Percentage of samples that tested positive for pathogenic gene markers during high-flow and normal-flow conditions.

[C. coli, Campylobacter coli; C. jejuni, Campylobacter jejuni, E. coli, Escherichia coli; n, number of samples; <, less than; nsd, no significant difference; p-value, p-value less than $0.05=$ significant difference between groups, Fisher's Exact Test]

\begin{tabular}{lccccccccc}
\hline $\begin{array}{l}\text { Water quality criteria' } \\
\text { status }\end{array}$ & $\mathbf{n}$ & eaeA & stx2 & stx1 & rfbo157 & ipaH & invA & spvC & $\begin{array}{c}\text { C. coli/C. } \\
\text { jejuni }\end{array}$ \\
\hline $\begin{array}{l}\text { Meet E. coli criterion } \\
\text { Exceed E. coli criterion }\end{array}$ & 24 & 60 & 11 & 3 & 5 & 7 & 0 & 9 & 6 \\
p-value & - & $<6$ & 50 & 42 & 33 & 4 & 33 & 33 & 21 \\
$\begin{array}{l}\text { Meet enterococci } \\
\quad \text { riterion }\end{array}$ & 67 & 54 & 10 & 5 & 3 & 6 & 0 & 3 & 2 \\
$\begin{array}{l}\text { Exceed enterococci } \\
\quad \text { riterion }\end{array}$ & 45 & 91 & 33 & 22 & 22 & 7 & 18 & 31 & 20 \\
p-value & - & $<0.05$ & $<0.05$ & $<0.05$ & nsd & $<0.05$ & $<0.05$ & $<0.05$ \\
\hline
\end{tabular}

${ }^{1}$ Water quality criteria = EPA Water Quality Criteria for Moderate Full Body Contact (Dufour and Ballantine, 1986). 


\section{Quality-Control Results}

To assess for bias and precision, 21 field blanks, 21 source solution blanks, and 22 field replicates were collected and processed in the same manner as the regular field samples. All field blanks and source solution water blanks were negative (no growth) for all FIB except for a sample collected at the River Raisin on August 30, 2011, which had an enterococci count of 2E (appendix 2). For PCR analysis, all no-template controls (negative controls) were found to be negative, and all positive assay controls yielded appropriate responses. However, the eae $A, r f b 0157$, and ipaH genes were infrequently detected in the field blanks and source solution blanks, most likely as a result of contamination in the source solution blank water (appendix 4). There were two dates-September 7, 2011, and August 24, 2011-for which environmental samples were collected in association with the source solution blank and field blank samples where there may have been possible contamination. The environmental sample, source solution blank, and field blank samples from these dates have been qualified with a "V" (analyte was detected in both the environmental sample and the associated blanks) as a result of possible contamination and data were not included in analyses (appendixes 3 and 4).

For all FIB field replicates, a relative standard deviation (RSD) was calculated and a mean RSD was computed (table 6) by using the formula below:

$$
S=\frac{\sqrt{(X 1-\bar{X})^{2}+(X 2-\bar{X})^{2}+(X 3-\bar{X})^{2}+\ldots}}{n-1}
$$

Table 6. Relative standard deviation of field replicates for quantitative microbial methods in the Great Lakes Restoration Initiative (GLRI) pathogens study.

[E. coli, Escherichia coli; RSD, relative standard deviation]

\begin{tabular}{llcc}
\hline \multicolumn{1}{c}{ Statistic } & E. coli & Enterococci & $\begin{array}{c}\text { Fecal } \\
\text { coliforms }\end{array}$ \\
\hline Average RSD, in percent & 25.3 & 28.4 & 31.1 \\
Number of field replicates & 22 & 22 & 22 \\
\hline
\end{tabular}

In all cases, the average RSD fell below the recommended 36 percent according to the initial and ongoing precision and recovery acceptance criteria that were used as a benchmark for replicate environmental samples (table 6) (EPA, 2009a).

For pathogen analysis, which yields only a presence or absence result, the frequencies of agreement between replicates were determined by dividing the number of paired replicates in agreement by the total number of replicates (table 7).

The field blank and source solution blank data results are presented in appendixes 2 and 4 . All replicate data are presented in appendixes 1 and 3, along with the associated environmental sample.

\section{Summary}

A total of 177 environmental samples were collected at USGS streamgaging stations during both normal-flow and high-flow conditions in 22 tributaries to the Great Lakes and were analyzed for the presence of FIB concentrations and to determine the occurrence of pathogen gene markers for Shigella species, Campylobacter jejuni and coli, Salmonella species, and pathogenic E. coli, including STEC. Results from a total of 165 samples were evaluated because 12 samples did not meet quality-control measures.

E. coli concentrations ranged from less than 2 to 26,000 CFU/100 mL. Enterococci concentrations ranged from less than 2 to $31,000 \mathrm{CFU} / 100 \mathrm{~mL}$. Fecal coliform bacteria concentrations ranged from less than 2 to $950 \mathrm{CFU} / 100 \mathrm{ml}$. Data from $E$. coli pathogen analyses showed that 68 percent of samples contained the eae $A$ gene, 20 percent of samples contained the stx 2 gene, 12 percent of samples contained the stxl gene, and 11 percent of samples contained the $r f b O 157$ gene. Data from the Shigella analysis showed that 6 percent of samples contained the ipaH gene. Data from the Salmonella analysis showed that 7 percent of samples contained the inv $A$ gene and 14 percent of samples contained the $s p v C$ gene. Data from the Campylobacter analysis showed that 9 percent of samples contained the $16 \mathrm{~S}$ rDNA gene of Campylobacter coli and Campylobacter jejuni.

Table 7. Frequency of agreement between field replicates for qualitative microbial methods in the Great Lakes Restoration Initiative (GLRI) pathogens study.

[C. coli, Campylobacter coli; C. jejuni, Campylobacter jejuni]

\begin{tabular}{lcccccccc}
\hline \multirow{2}{*}{ Statistic } & \multicolumn{8}{c}{ Pathogen gene markers } \\
\cline { 2 - 9 } & eaeA & stx2 & stx1 & rfb0157 & ipaH & invA & spvC & C. coli/C. jejuni \\
\hline Percent agreement & 82 & 95 & 95 & 82 & 100 & 95 & 91 & 95 \\
Number of field replicates & 22 & 22 & 22 & 22 & 22 & 22 & 22 & 22 \\
\hline
\end{tabular}


There were no samples in which all eight pathogen gene markers were detected; however, 88 percent of the samples that had three or more pathogen gene markers present were collected during high-flow conditions. Overall, there were a higher percentage of samples that tested positive for pathogens during high-flow conditions than normal-flow conditions, and there was a greater occurrence of pathogen gene markers in samples that exceeded the EPA moderate full body contact recreation criteria for E. coli and enterococci (Dufour, 1986) than in samples that met the EPA criteria; the exception was a greater occurrence of the ipaH gene marker for Shigella in samples that met the EPA criterion for E. coli than in samples that exceeded the EPA criterion for E. coli.

\section{Acknowledgements}

This study was funded by the Great Lakes Restoration Initiative. We wish to acknowledge the many USGS personnel from Indiana, Michigan, Minnesota, Ohio, New York and Wisconsin who collected the water samples for this project and communicated with the Michigan Bacteriological Research Laboratory.

\section{References Cited}

American Public Health Association, American Water Works Association, and Water Environment Federation, 1998, Standard methods for the examination of water and wastewater (20th ed.): Washington, D.C., American Public Health Association, p. 9-1 to 9-76.

Centers for Disease Control and Prevention (CDC), 2012a, Campylobacter: CDC Web page, accessed April 17, 2012, at http://www.cdc.gov/nczved/dfbmd/diseases/campylobacter/.

Centers for Disease Control and Prevention (CDC), 2012b, Recreational Water Illnesses (RWIs): CDC Web page, accessed April 17, 2012, at http://www.cdc.gov/healthywater/swimming/rwi/.

Centers for Disease Control and Prevention (CDC), 2012c, Salmonella: CDC Web page, accessed April 17, 2012, at http://www.cdc.gov/salmonella.

Centers for Disease Control and Prevention (CDC), 2012d, STEC: CDC Web page, accessed April 17, 2012, at http:// www.cdc.gov/ecoli/index.html.

Dufour, A.P., and Ballantine, R.K., 1986, Ambient water quality criteria for bacteria, 1986-Bacteriological ambient water quality criteria for marine and freshwater recreational waters: Washington, D.C., EPA 440/5-84-002.
Great Lakes Information Network (GLIN), 2013, Great Lakes facts and figures: GLIN Web page, accessed May 6, 2013, at http://www.glin.net/lakes/ref/lakefact.html.

Haack, S.K., Fogarty, L.R., Stelzer, E.A., Fuller, L.M, Brennan, A.K, Isaacs, N.M., and Johnson, H.E. 2013, Geographic setting influences great lakes beach microbiological water quality: Environmental Science \& Technology, v. 47, no. 21, p. 12054-12063.

Myers, D.N., Stoeckel, D.M., Bushon, R.N., Francy, D.S., and Brady, A.M.G., 2014, Fecal indicator bacteria (ver. 2.1): U.S. Geological Survey Techniques of Water-Resources Investigations, book 9, chap. A7, section 7.1, May 2014, accessed June 2014 at $h$ ttp://pubs.water.usgs.gov/twri9A/.

U.S. Environmental Protection Agency (EPA), 2004, Quality assurance/quality control guidance for laboratories performing PCR analysis on environmental samples: Office of Water, EPA 815-B-04-001, 56 p.

U.S. Environmental Protection Agency (EPA), 2009a, Method 1603 "Escherichia coli in water by membrane filtration using modified membrane-thermotolerant Escherichia coli agar": Washington, D.C., EPA-821-R-09-007 [variously paged].

U.S. Environmental Protection Agency (EPA), 2009b, Method 1600 "Enterococci in water by membrane filtrations using membrane-Enterococcus indoxyl- $\beta$-D-glucoside agar": Washington, D.C., EPA-821-R-09-016 [variously paged].

U.S. Environmental Protection Agency (EPA), 2012, Recreational water quality criteria: Office of Water, EPA 815-F-12-058, $63 \mathrm{p}$.

U.S. Environmental Protection Agency (EPA) and U.S. Geological Survey (USGS), 2012, National Hydrography Dataset Plus - NHDPlus version 2.1, accessed May 2012 at http://www.horizon-systems.com/NHDPlus/NHDPlusV2_ home.php.

U.S. Geological Survey (USGS), 2006, Collection of water samples (ver. 2.0): U.S. Geological Survey Techniques of Water-Resources Investigations, book 9, chap. A4, September 2006, accessed June 1, 2014, at http://pubs.water.usgs. gov/twri9A4/.

U.S. Geological Survey (USGS), 2011, National Land Cover Database (NLCD) 2006 Land Cover, accessed April 3, 2012, at http://www.mrlc.gov/nlcd06_data.php.

U.S. Geological Survey (USGS), Great Lakes Restoration Initiative (GLRI), 2014, Forecast/nowcast Great Lakes nutrient and sediment loadings: USGS/GLRI Web page, accessed March 6, 2014, at http://cida.usgs.gov/glri/projects/nearshore_health/forecast_loadings.html. 



\section{Appendixes}

1. Fecal indicator bacteria concentrations in Great Lakes tributaries, 2011 .......................14

2. Quality-control data-Fecal indicator bacteria concentrations in Great Lakes

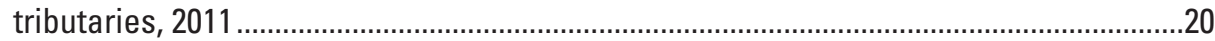

3. Pathogen gene detection in Great Lakes tributaries, 2011 ............................................22

4. Quality-control data_Pathogen gene detection in Great Lakes tributaries, 2011 ........28 


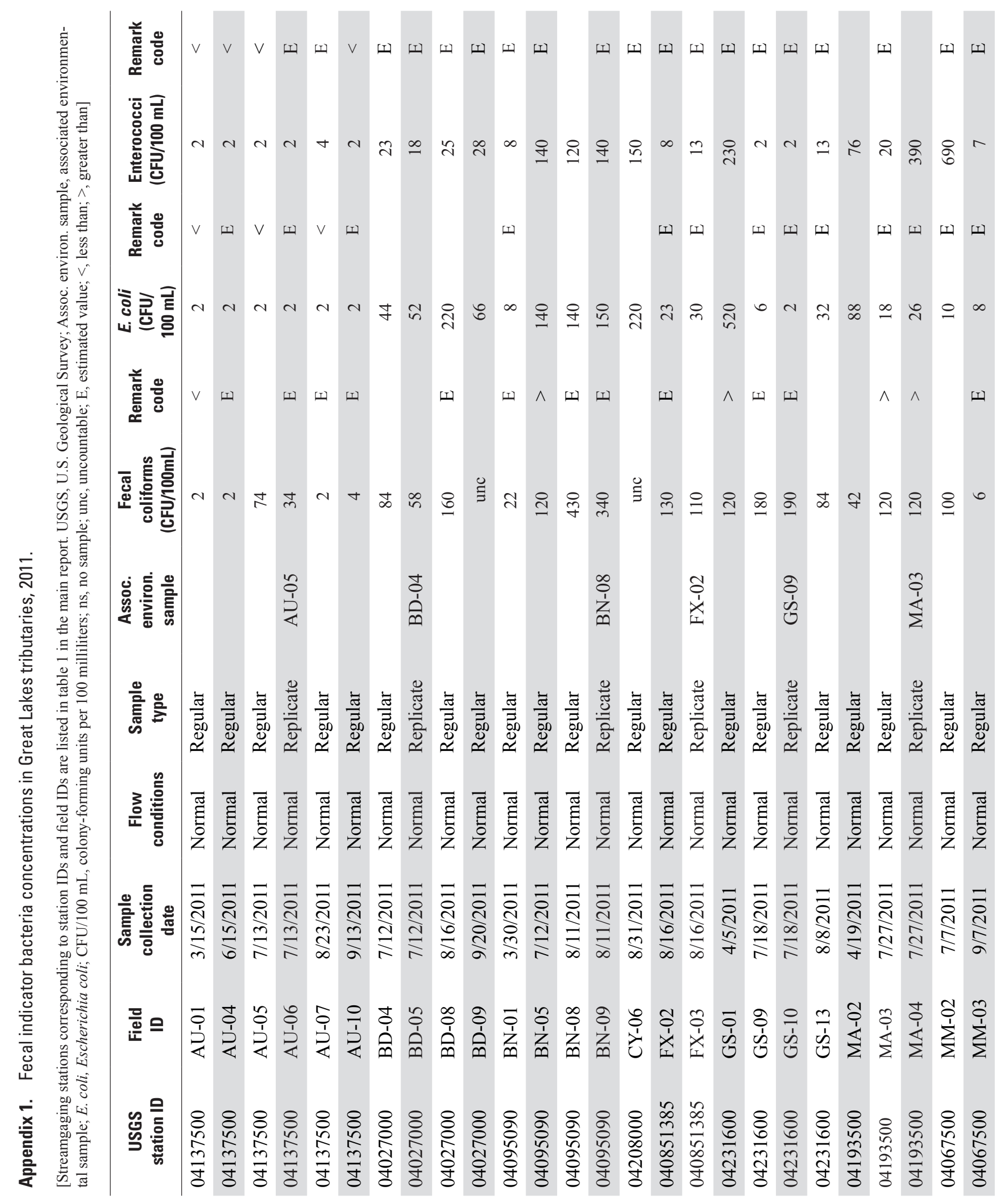




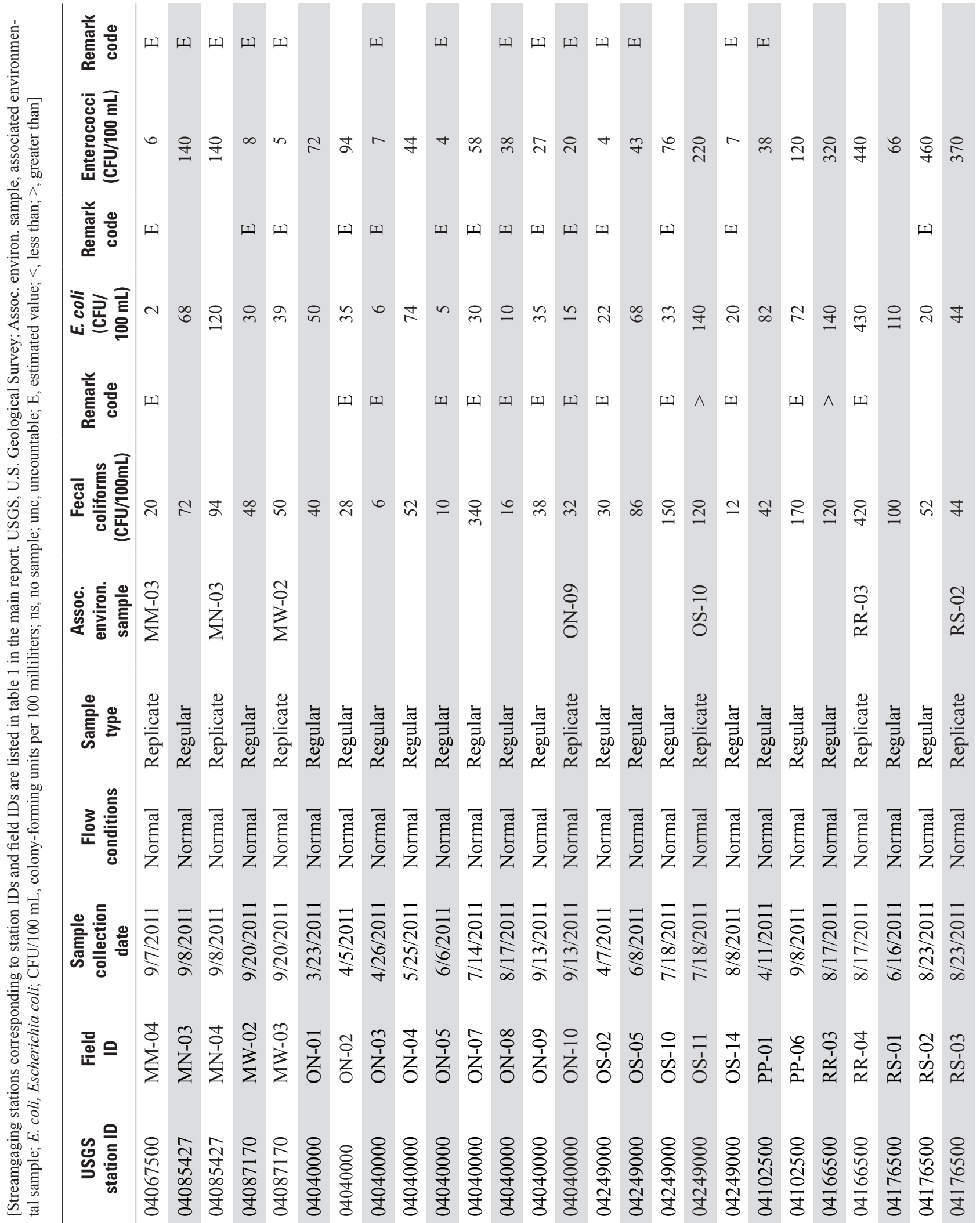




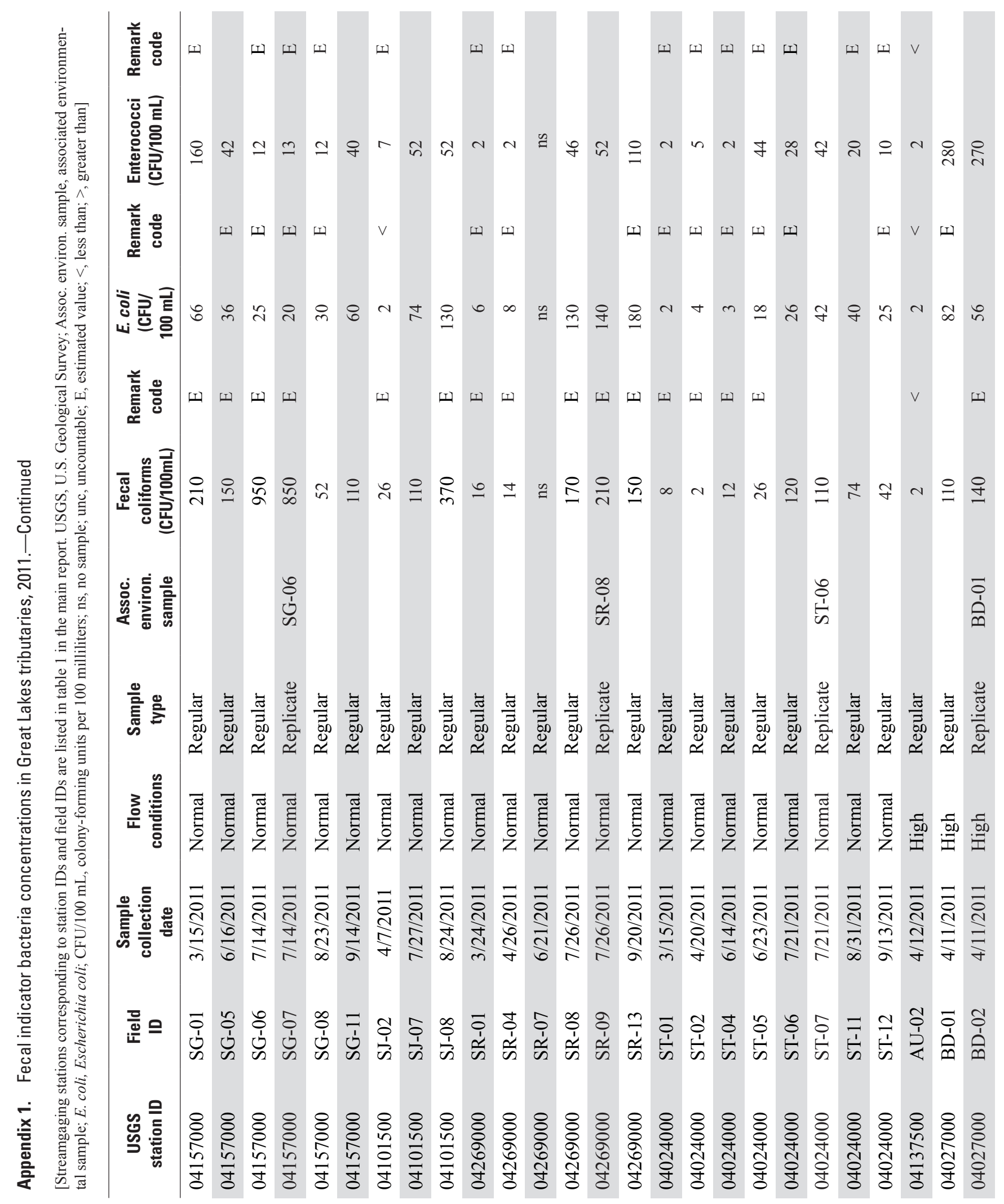




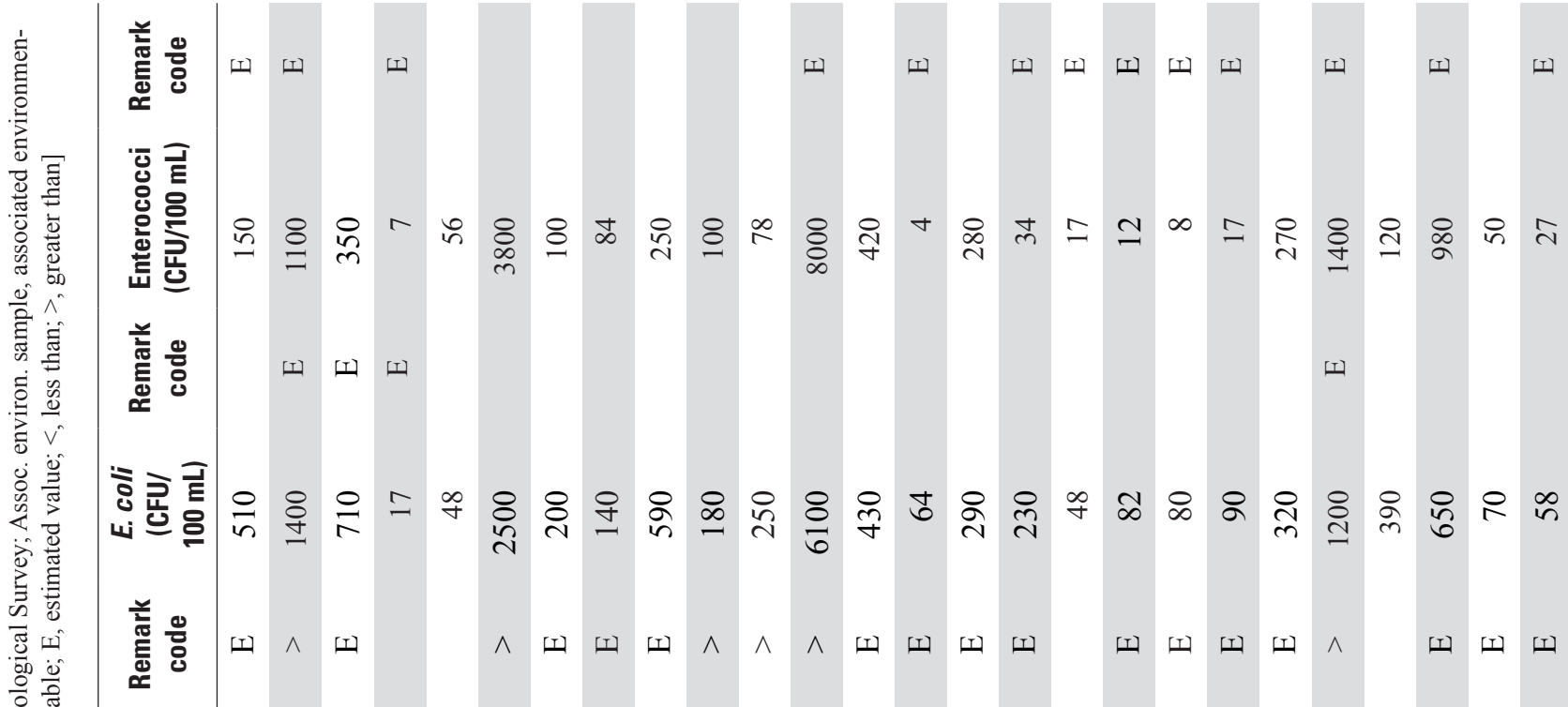

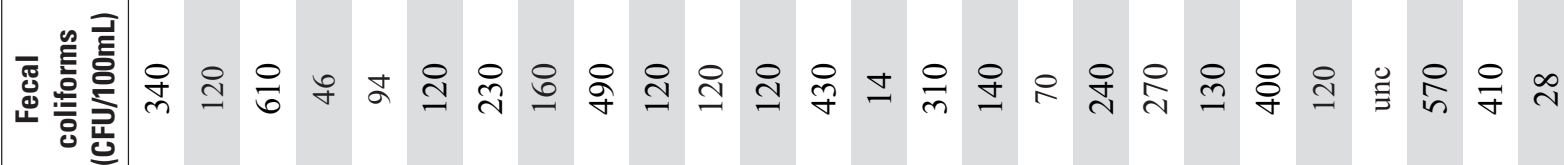
递竞言

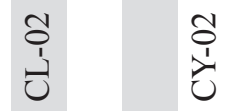

章
峁

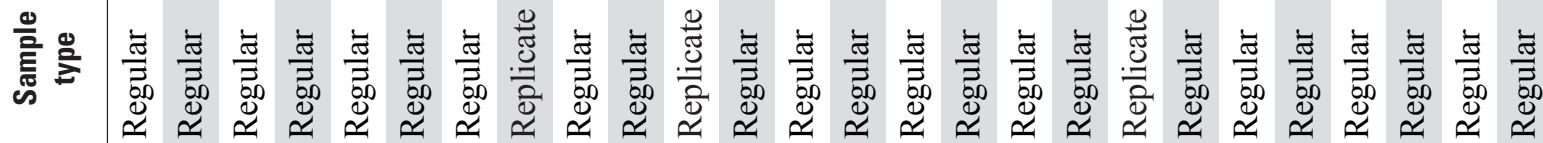
른

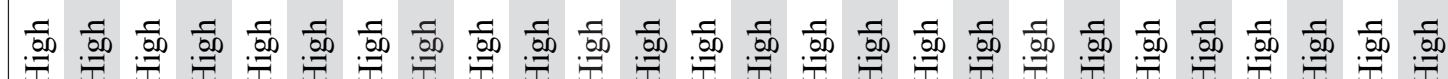

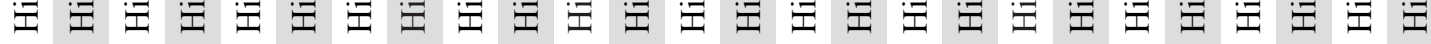




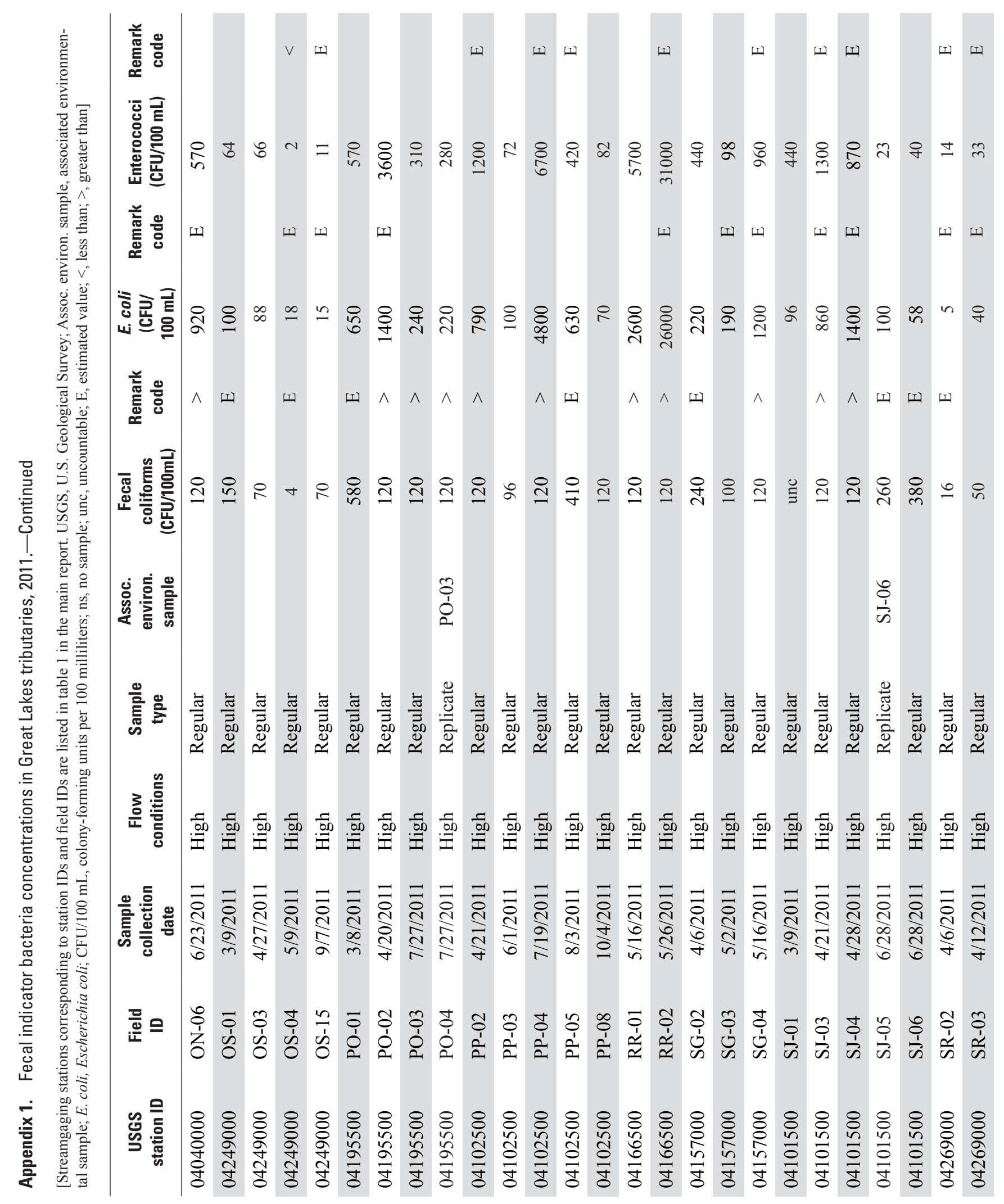




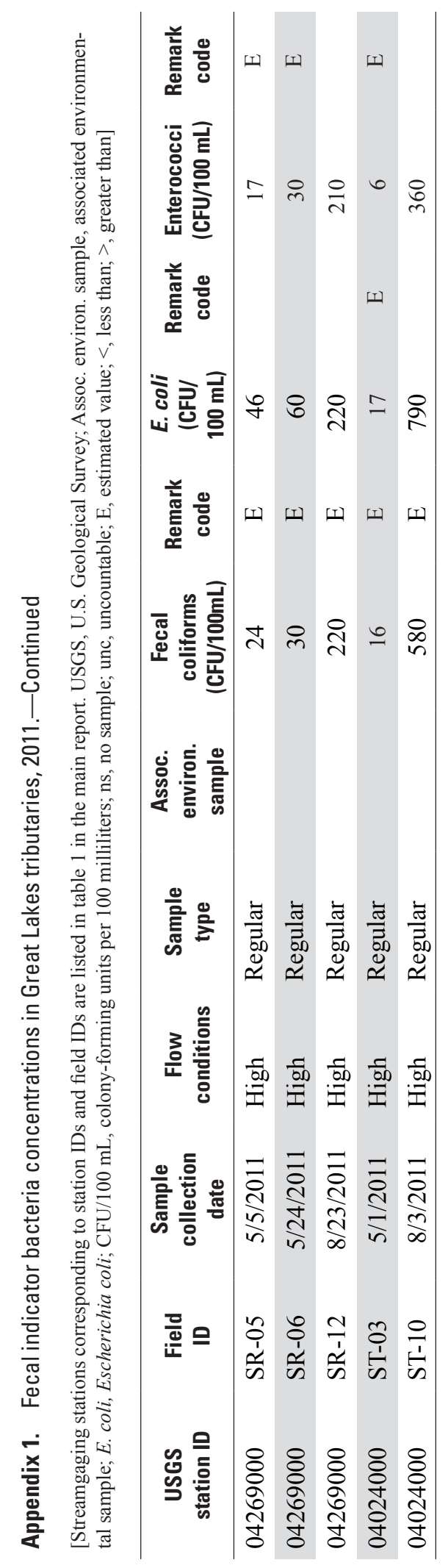




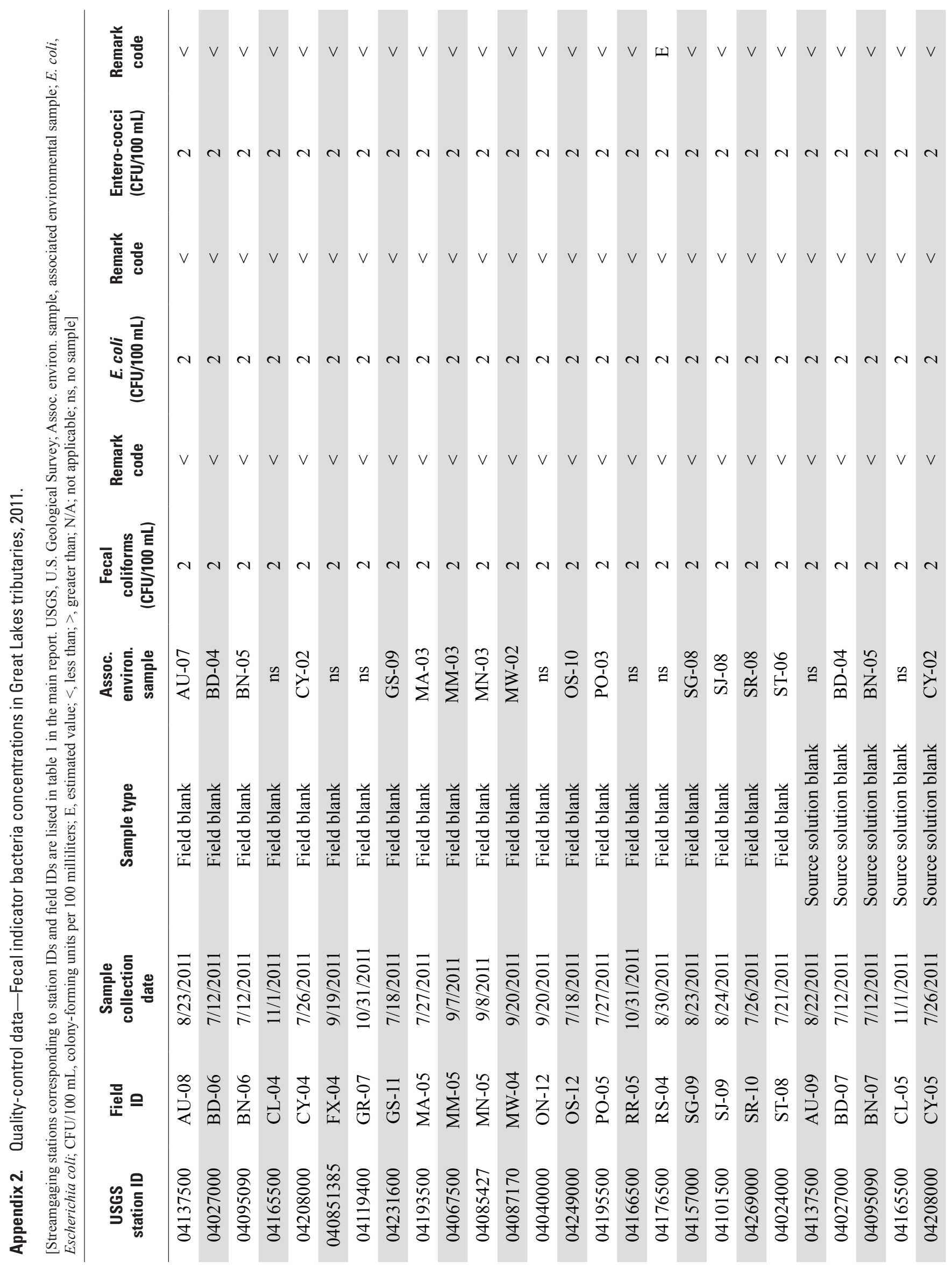




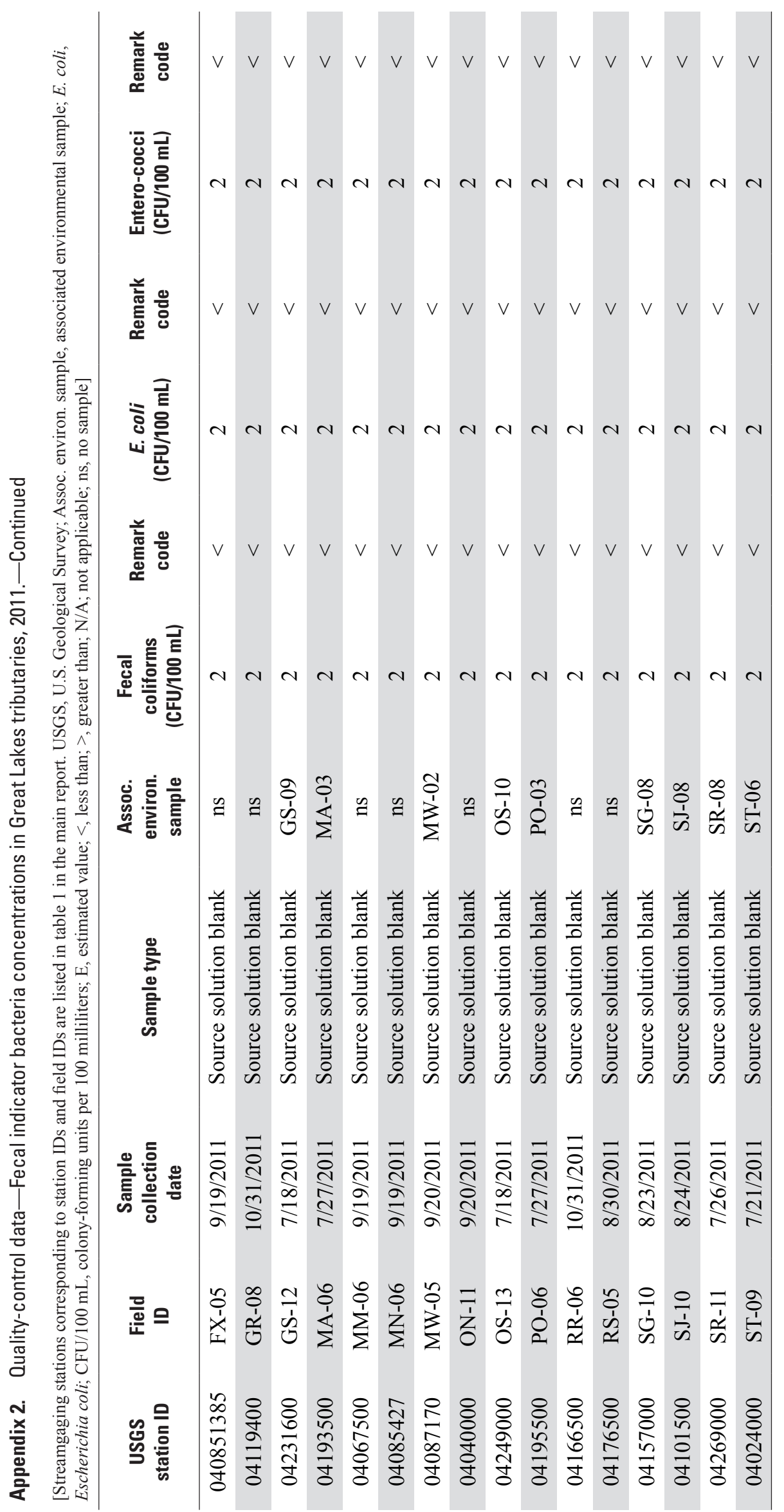




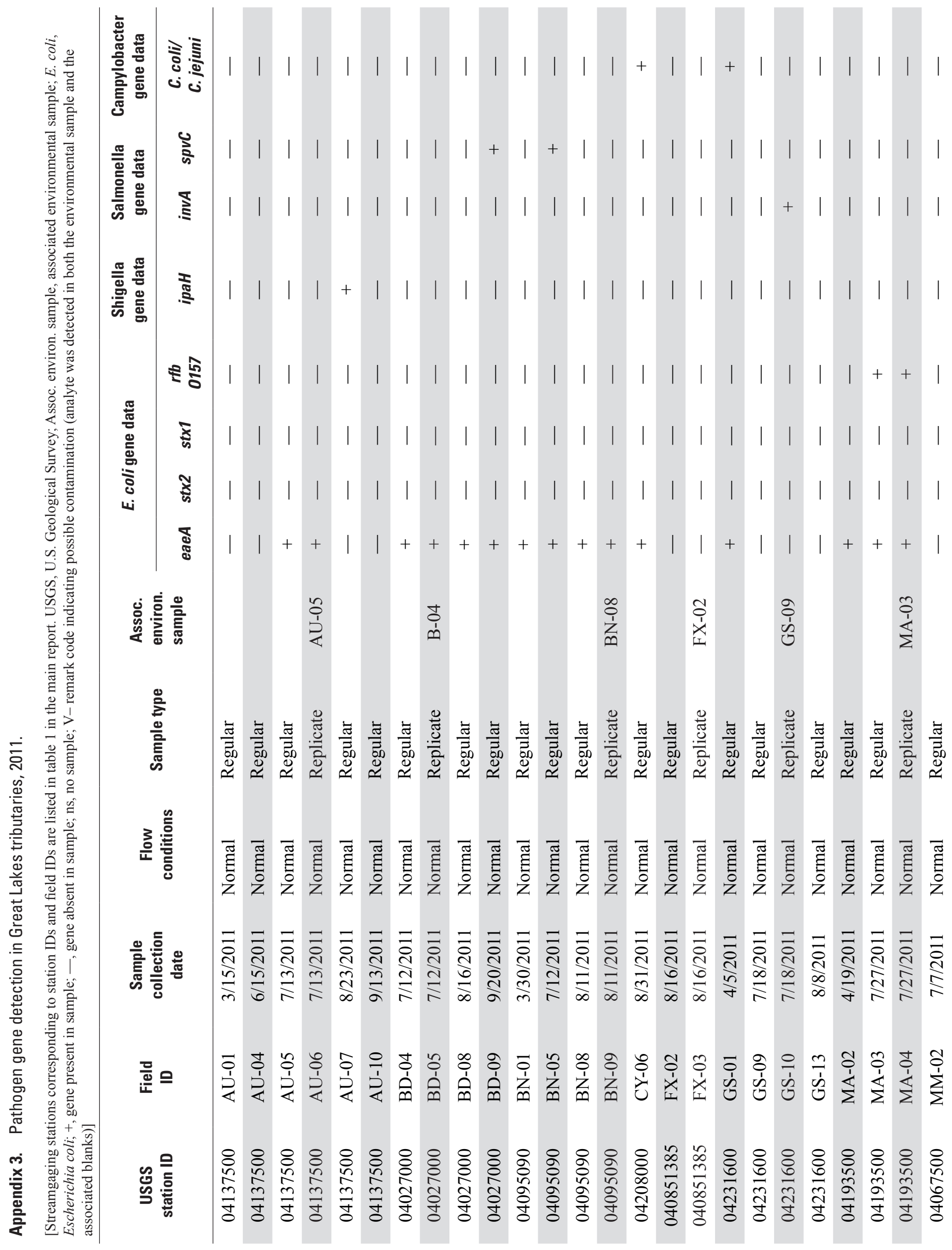




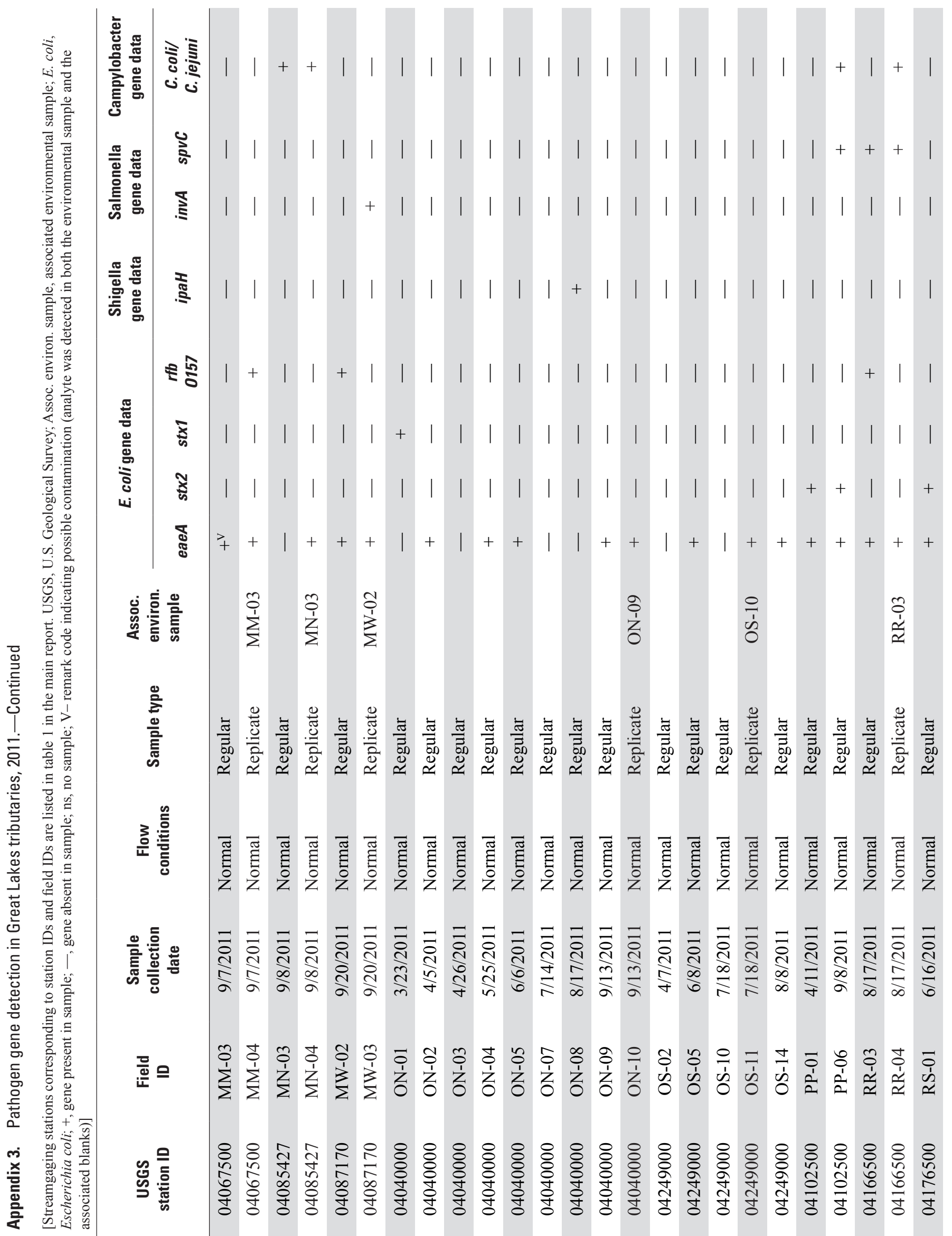




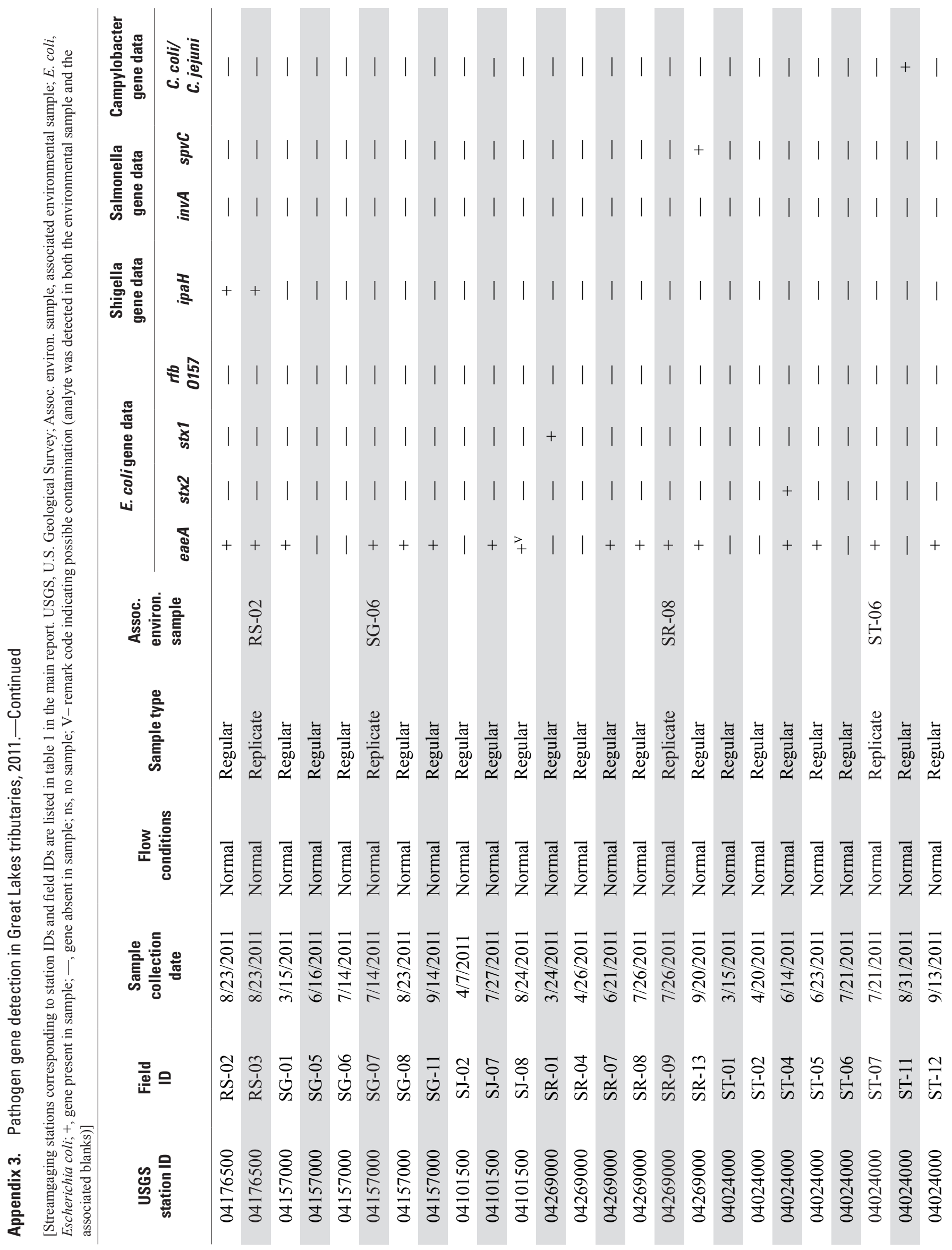




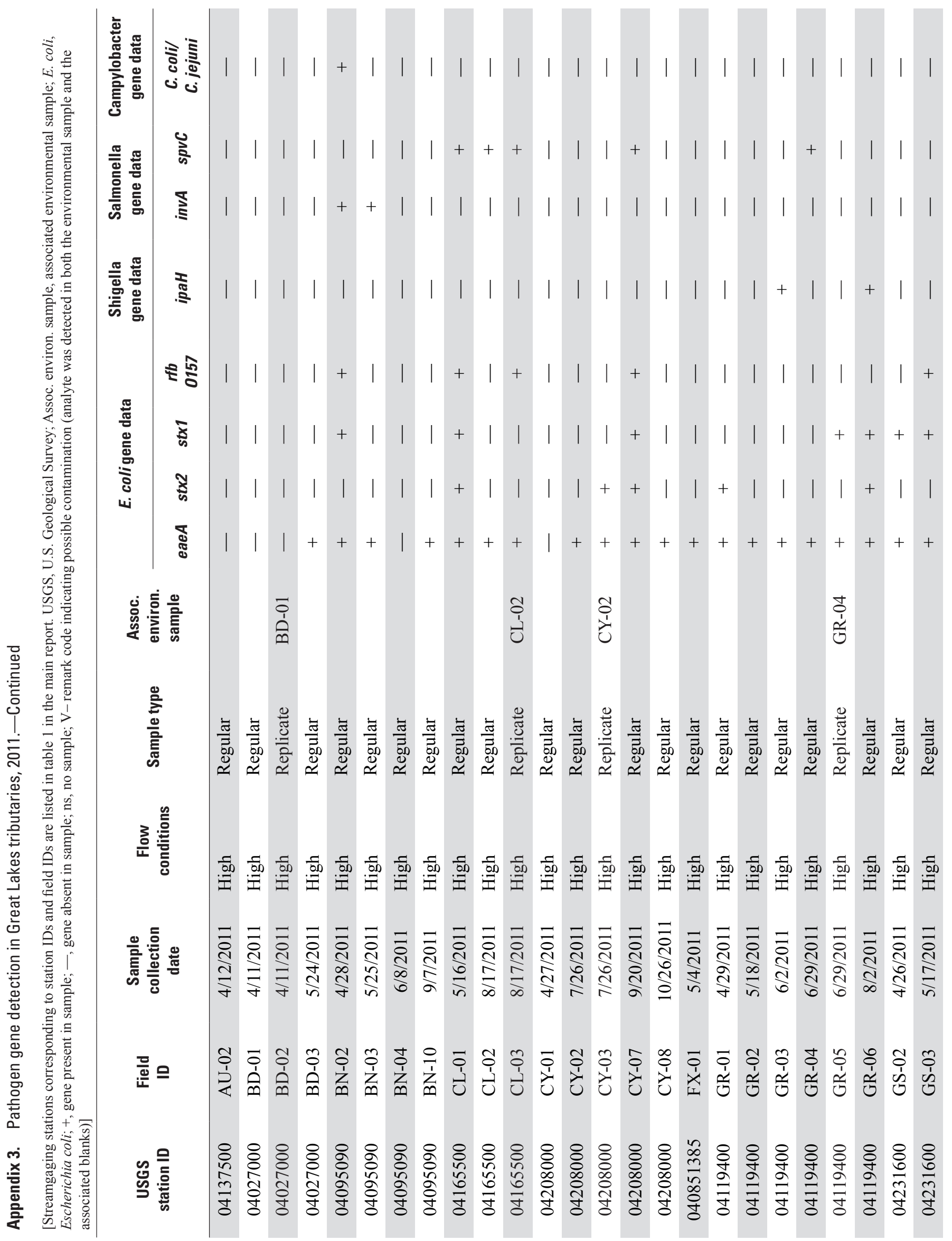




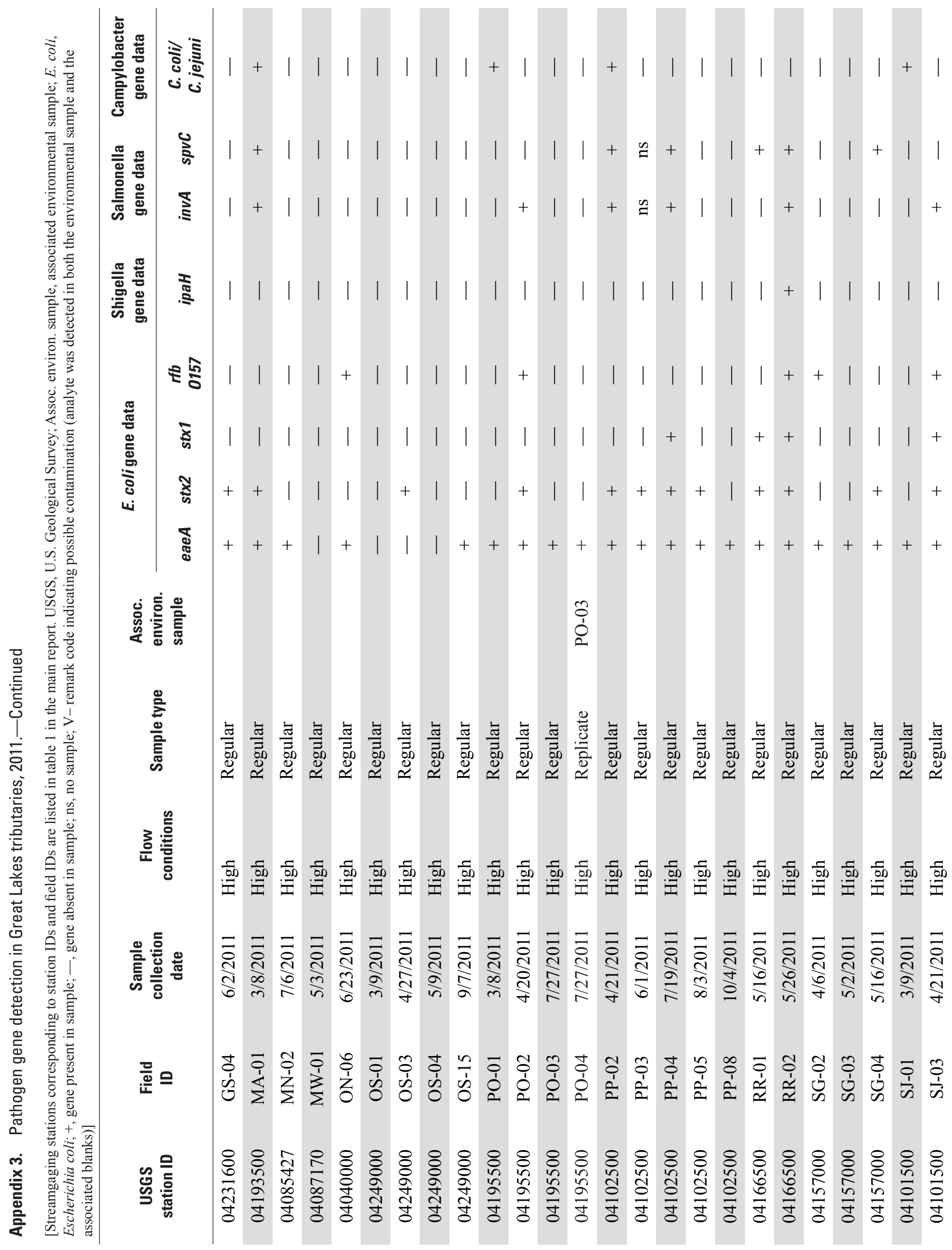




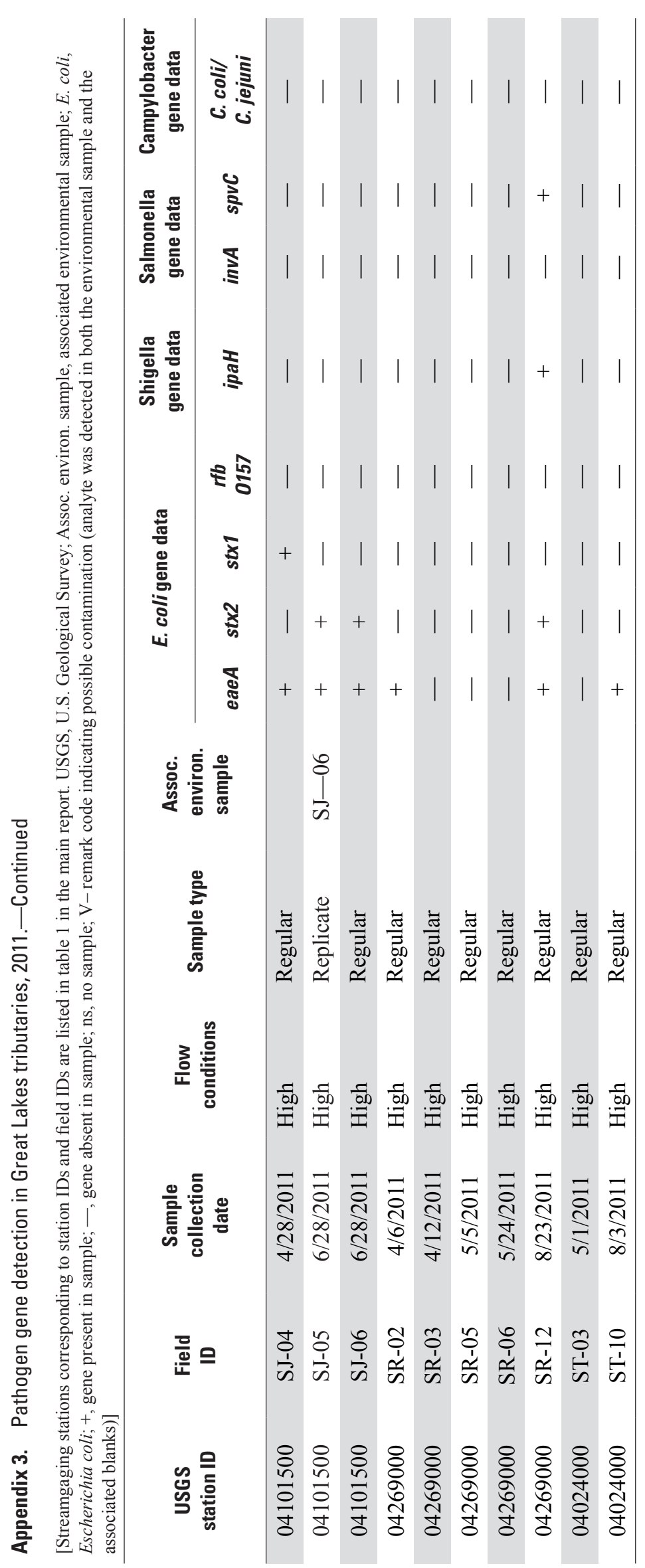




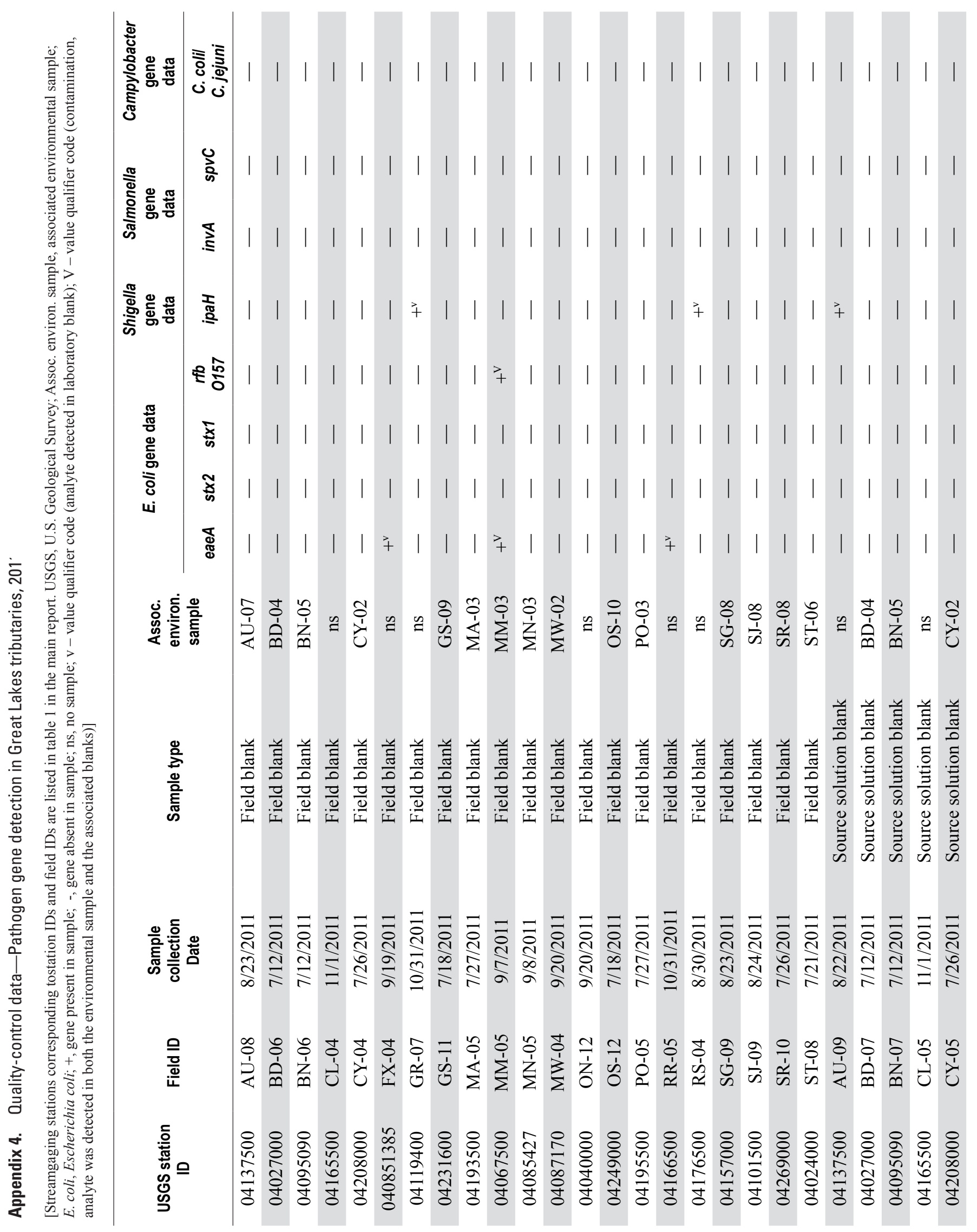




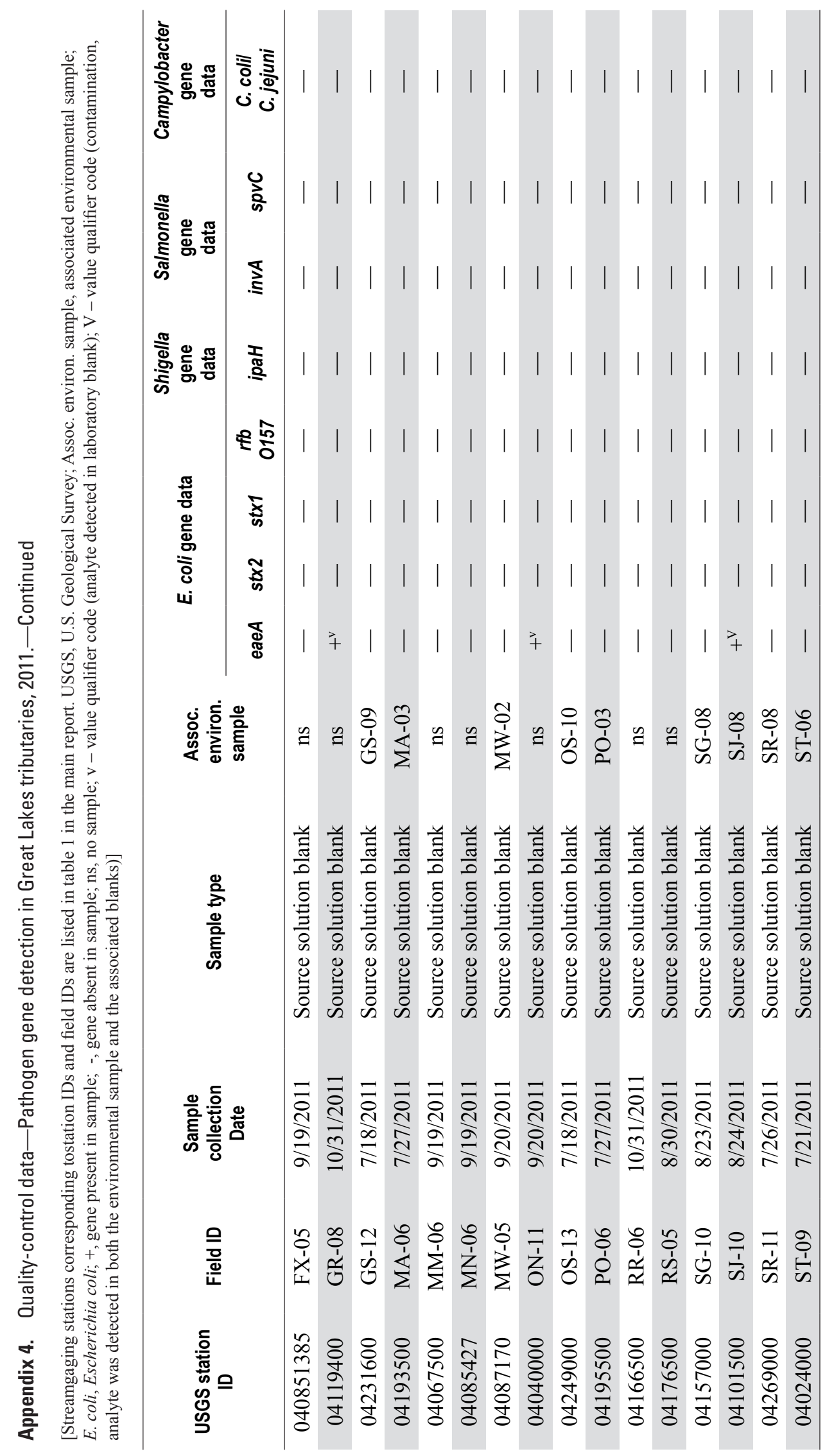



